Review

\title{
Preparation and Modification of Biochar Materials and their Application in Soil Remediation
}

\author{
Xue Yang, Shiqiu Zhang, Meiting Ju*D and Le Liu * \\ College of Environmental Science and Engineering, Nankai University, Tianjin 300350, China; \\ 2120170638@mail.nankai.edu.cn (X.Y.); swustzsq@sina.com (S.Z.) \\ * Correspondence: nkujumeiting@sohu.com (M.J.); tjliule@126.com (L.L.); Tel.: +86-13820988813 (M.J.); \\ +86-13672031215 (L.L.)
}

Received: 28 February 2019; Accepted: 25 March 2019; Published: 1 April 2019

\begin{abstract}
As a new functional material, biochar was usually prepared from biomass and solid wastes such as agricultural and forestry waste, sludge, livestock, and poultry manure. The wide application of biochar is due to its abilities to remove pollutants, remediate contaminated soil, and reduce greenhouse gas emissions. In this paper, the influence of preparation methods, process parameters, and modification methods on the physicochemical properties of biochar were discussed, as well as the mechanisms of biochar in the remediation of soil pollution. The biochar applications in soil remediation in the past years were summarized, such as the removal of heavy metals and persistent organic pollutants (POPs), and the improvement of soil quality. Finally, the potential risks of biochar application and the future research directions were analyzed.
\end{abstract}

Keywords: biochar preparation; soil pollution; remediation

\section{Introduction}

With the development of industry and high-intensity human activities in China, soil pollution is becoming more and more serious, mainly due to the reduction of soil area and pollution by chemical compounds such as pesticides, petroleum, heavy metals, persistent organic matter, and acidic substances [1].

Pollutants in soil mainly include heavy metals and organic compounds, such as $\mathrm{Cd}, \mathrm{Pb}, \mathrm{Cr}$, pesticides, fertilizers, antibiotics, polycyclic aromatic hydrocarbons (PAHs), polychlorinated biphenyls (PCBs), etc. [2,3]. These pollutants not only affect the decline of crop yield and quality, resulting in further deterioration of the atmospheric and water environment quality, but also have carcinogenic, teratogenic, mutagenic effects, and genotoxicity, which endanger human health through the food chain [4].

The remediation methods of contaminated soil are mainly divided into physical, chemical, biological, and plant methods. Physical remediation technologies mainly include soil leaching, thermal desorption, steam extraction, and off-site landfill [5]. But the disadvantages are its high costs and the risk of secondary diffusion. Chemical remediation technologies mainly include immobilization-stabilization techniques, redox, chemical modification, surfactant cleaning, and organic matter improvement $[6,7]$, but the chemicals used may cause secondary pollution to the environment. There is a long repair cycle in bioremediation technology and the repair effect is susceptible to external environmental factors.

Since Lehmann proposed the efficacy of Amazon black soil [8], scholars have found that the biochar produced by the lack of oxygen through pyrolysis of agricultural and forestry wastes is a material with well-developed pore structure, large specific surface area, abundant oxygen-containing functional groups, and excellent adsorption performance $[9,10]$. Biochar remediation technology is 
between physical remediation and chemical remediation. On one hand, inorganic pollutants could be removed by physical adsorption, and organic pollutants could be removed by distribution. On the other hand, the application of biochar affects the solubility, valence, and existence of heavy metals in the soil, thus immobilizing the heavy metals in the soil. Finally, toxicity of heavy metals was fixed or reduced [9]. Due to its remarkable effect, low cost, and convenient operation, biochar has advantages in the treatment of heavy metal and organic pollution [11].

Before summarizing the application of biochar in soil remediation, this paper summarized the preparation and modification methods of biochar and analyzed the influence of different processes on the physicochemical properties of biochar to deepen the understanding of biochar. As the adsorbing material, the removal of heavy metals and organic compounds from soil and the main mechanism of biochar were reviewed. As a soil improver, the improvement of soil $\mathrm{pH}$, nutrient, nitrogen, and phosphorus loss by biochar, and the application trend in the future, were summarized. At the same time, the potential risks of biochar were analyzed to effectively avoid the possible harm to the environment.

\section{Preparation and Modification of Biochar}

\subsection{Preparation of Biochar}

The preparation methods of biochar are mainly divided into pyrolysis [12], hydrothermal carbonization (HTC) [13], and microwave carbonization [14]. Different preparation methods affect the physical and chemical properties of biochar, such as yield, ash, specific surface area, pore structure, type and number of functional groups, and cation exchange capacity. Compared with the pyrolysis, HTC does not require drying step and has a higher biochar yield [15]. The advantages of microwave carbonization are controllable process, no hysteresis, rapid heating, and energy efficiency $[16,17]$. However, biochar prepared through HTC and microwave contained high concentrations of organics, which are not actually considered soil remediation material.

\subsubsection{Pyrolysis}

Pyrolysis, also known as the thermal decomposition under oxygen-free conditions, is the most common method for preparing biochar. In general, pyrolysis involves the heating of organic materials to temperatures greater than $400{ }^{\circ} \mathrm{C}$ under inert atmospheres by electric heating or high-temperature medium. There are many parameters influence physicochemical properties of biochar, such as raw material, reaction temperature, heating rate, residence time, and reaction atmosphere.

\subsubsection{Factors Affecting the Pyrolysis Process}

The raw materials for the preparation of biochar are abundant. Basically, any form of organic materials can be pyrolyzed [18]. Due to the large output of biomass solid waste resources, biomass is a common raw material for biochar, mainly including wheat straw, corn straw, wood chips, melon seed shell, peanut shell, rice husk, livestock and poultry manure, kitchen waste, sludge, fruit skin, etc. [19]. Biochar prepared from different materials contains different proportions of cellulose, hemicellulose, and lignin, so its yield, element composition, and ash content are different [20,21]. Enders et al. [22] found that the ash content of straw biochar is higher than that of other biochar, which is mainly caused by the high Si content of straw. Yuan et al. [23] compared the physicochemical properties of biochar prepared from different feedstocks (the straws of canola, corn, soybean, and peanut). The ash content of biochar from corn straw prepared at $700{ }^{\circ} \mathrm{C}$ was the highest (73.30\%), compared to canola, soybean, and peanut straw biochar $(28.55 \%, 23.70 \%, 38.50 \%$, respectively).

The reaction temperature ranges of high temperature anoxic, hydrothermal synthesis, and flash carbonization for the preparation of biochar are $400-900{ }^{\circ} \mathrm{C}, 180-250{ }^{\circ} \mathrm{C}$, and $300-600{ }^{\circ} \mathrm{C}$, respectively [11]. In general, with the increase of pyrolysis temperature, the yield of biochar and the number of acidic functional groups $(-\mathrm{COOH},-\mathrm{OH})$ decreased, while the alkaline functional groups, ash content, and $\mathrm{pH}$ increased. In addition, the effects of pyrolysis temperature on the surface area and 
pore volume are especially significant. Park et al. [24] showed that the specific surface area and total pore volume of sesame straw biochar increased from 46.9 to $289.2 \mathrm{~m}^{2} \cdot \mathrm{g}^{-1}, 0.0716$ to $0.1433 \mathrm{~cm}^{3} \cdot \mathrm{g}^{-1}$, respectively, with the pyrolysis temperature increased from 500 to $600{ }^{\circ} \mathrm{C}$.

According to the different heating rate, it could be divided into slow pyrolysis (SP) and fast pyrolysis (FP) [25]. SP is characterized by slow heating (minutes to hours) of the organic material in the oxygen-depleted atmosphere and relatively long solids and gas residence times [26,27]. During the SP process, liquid and solid products such as char, bio-oil, and syngas $\left(\mathrm{CO}, \mathrm{CO}_{2}, \mathrm{H}_{2}\right)$ are produced. The FP involves blowing small particles of organic material into a thermal reactor and exposing it to heat transfer in milliseconds to seconds [18]. Modern FP often takes place in fluidized bed systems, systems using ablative reactors, and systems using pyrolysis centrifuge reactors (PCR) [28]. Slow and fast pyrolysis results in biochars with different physicochemical properties, thus providing different effects on the soil environment upon application. Compared with the FP-biochar contained labile un-pyrolyzed biomass fraction, the SP-biochar can be pyrolyzed completely [26].

At the same pyrolysis temperature, the yield of biochar decreases with the increase of residence time. Chen et al. [29] prepared orange peel biochar with the pyrolysis temperature of $700{ }^{\circ} \mathrm{C}$ and residence time of $6 \mathrm{~h}$, and the biochar yield was only 5.93\%. The specific surface area and pores of biochar increased with the extension of residence time. But the residence time is not as long as possible. $\mathrm{Lu}$ et al. [30] found that the specific surface area and pores decreased from 2 to $3 \mathrm{~h}$. The reason is that the increase of residence time is conducive to the development of biochar pores, but excessive residence time may cause damage to the pore structure [31].

The reaction atmosphere studied by scholars is dominated by inert gas, such as $\mathrm{N}_{2}$, Ar, which mainly act to isolate oxygen. Besides, the atmosphere of $\mathrm{CO}_{2}, \mathrm{H}_{2} \mathrm{O}, \mathrm{NH}_{3}, \mathrm{O}_{3}$ [32] is also used to prepare biochar, which is known as physical activation, also called gas activation. The gases selectively decompose the non-structural components of the biochar surface, open its internal pores, and increase the specific surface area and pore volume [11]. Table 1 lists the biochar prepared by different process parameters.

\subsubsection{Other New Methods}

In addition to the pyrolysis, hydrothermal carbonization, and microwave carbonization discussed above, flash carbonization and torrefaction [33] are other methods of biomass transformation. During the flash carbonization process, the flash fire is ignited at a high pressure (1-2 Mpa) on the biomass packed bed to convert the biomass into the gas and solid phase products [11]. It is reported that about $40 \%$ of biomass is converted to solid phase products (biochar) at $1 \mathrm{Mpa}$ [34]. In addition to microwave, new pyrolysis technologies such as laser and plasma cracking technologies have also been developed. The sample usage of laser pyrolysis technology is small, and rapid heating and cooling can be carried out, which can effectively avoid the occurrence of secondary reactions [35]. Plasma pyrolysis technology is mainly applied in the preparation of syngas and coke. Compared with the traditional cracking technology, it can greatly increase the syngas and reduce the yield of bio-oil [36,37]. However, it is difficult to popularize the new pyrolysis technology due to its high cost and energy consumption. 
Table 1. Physicochemical properties of biochar prepared by different methods and process parameters.

\begin{tabular}{|c|c|c|c|c|c|c|c|c|c|c|c|}
\hline Raw Material & Atmosphere & $\begin{array}{c}\text { Temperature } \\
\left({ }^{\circ} \mathrm{C}\right)\end{array}$ & $\begin{array}{c}\text { Heating } \\
\text { Rate } \\
\left({ }^{\circ} \mathrm{C} / \mathrm{min}\right)\end{array}$ & $\begin{array}{c}\text { Residence } \\
\text { Time (h) }\end{array}$ & Yield (\%) & $\mathrm{pH}$ & $\begin{array}{c}\text { Ash } \\
\text { Content } \\
(\%)\end{array}$ & $\begin{array}{c}\text { Surface } \\
\text { Area } \\
\left(\mathrm{m}^{2} \cdot \mathrm{g}^{-1}\right)\end{array}$ & $\begin{array}{c}\text { Total Pore } \\
\text { Volume } \\
\left(\mathrm{cm}^{3} \cdot \mathrm{g}^{-1}\right)\end{array}$ & $\begin{array}{c}\text { Pore } \\
\text { Diameter } \\
(\mathrm{nm})\end{array}$ & Reference \\
\hline \multirow{4}{*}{ Herb residue } & \multirow{4}{*}{$\mathrm{N}_{2}$} & 400 & \multirow{4}{*}{10} & \multirow{4}{*}{3} & 37.9 & 10.2 & 28.3 & 49.2 & 0.042 & 3.39 & \multirow{3}{*}{ [38] } \\
\hline & & 600 & & & 31.2 & 10.1 & 31.1 & 51.3 & 0.051 & 3.99 & \\
\hline & & 800 & & & 29.1 & 10.6 & 37.1 & 70.3 & 0.068 & 3.87 & \\
\hline & & 400 & & & 35.6 & & 30.77 & 37.2 & 0.0542 & & \multirow{3}{*}{ [24] } \\
\hline \multirow{2}{*}{ Sesame straw } & \multirow{2}{*}{ oxygen-limited } & 500 & \multirow[t]{2}{*}{5} & \multirow[t]{2}{*}{2} & 28.2 & & 28.54 & 46.9 & 0.0716 & & \\
\hline & & 600 & & & 22.9 & & 21.98 & 289.2 & 0.1433 & & \\
\hline Corn straw & $\mathrm{N}_{2}$ & 600 & & 3 & & 10.0 & 5.02 & 61.0 & 0.036 & 23.7 & [39] \\
\hline Pine cone & $\mathrm{N}_{2}$ & 500 & & 1 & & 4.66 & 2.13 & 6.6 & 0.016 & & [40] \\
\hline Rice-husk & & $450-500$ & & & & 7.0 & 42.2 & 34.4 & 0.028 & & {$[41]$} \\
\hline \multirow{2}{*}{ Hickory wood } & \multirow{2}{*}{$\mathrm{N}_{2}$} & 450 & \multirow[b]{2}{*}{10} & \multirow[b]{2}{*}{2} & 28.5 & 7.9 & 6.47 & 12.9 & & & \multirow{6}{*}{ [42] } \\
\hline & & 600 & & & 22.7 & 8.4 & 4.18 & 401.0 & & & \\
\hline & & 450 & & & 28.0 & 7.5 & 13.68 & 13.6 & & & \\
\hline Bagasse & $\mathrm{N}_{2}$ & 600 & 10 & 2 & 26.5 & 7.5 & 15.36 & 388.3 & & & \\
\hline \multirow{2}{*}{ Bamboo } & \multirow[b]{2}{*}{$\mathrm{N}_{2}$} & 450 & \multirow[b]{2}{*}{10} & \multirow[b]{2}{*}{2} & 26.3 & 8.5 & 8.83 & 10.2 & & & \\
\hline & & 600 & & & 24.0 & 9.2 & 11.86 & 375.5 & & & \\
\hline \multirow{2}{*}{$\begin{array}{l}\text { Poplar chips } \\
\text { Burcucumber } \\
\text { plants }\end{array}$} & $\mathrm{N}_{2}$ & 550 & 5 & 2 & 23.18 & & 7.56 & 212.58 & 0.356 & 6.70 & [43] \\
\hline & oxygen-limited & 700 & 7 & 2 & 27.52 & 12.23 & 43.72 & 2.31 & 0.008 & 6.780 & [44] \\
\hline Pine wood & $\mathrm{N}_{2}$ & 600 & 10 & 1 & & & 4.02 & 209.6 & 0.003 & & [45] \\
\hline \multirow{2}{*}{ Orange peel } & \multirow{2}{*}{ oxygen-limited } & 400 & 5 & 6 & 11.3 & & 6.93 & 28.1 & 0.0409 & 2.9 & \multirow{2}{*}{ [29] } \\
\hline & & 700 & 5 & 6 & 5.93 & & 14.9 & 501 & 0.390 & 1.6 & \\
\hline $\begin{array}{c}\text { Marine } \\
\text { macroalgae }\end{array}$ & $\mathrm{N}_{2}$ & 450 & 5 & 2 & & & & 1.05 & 0.007 & 30.41 & [46] \\
\hline \multirow{3}{*}{$\begin{array}{l}\text { Municipal } \\
\text { solid waste }\end{array}$} & \multirow{3}{*}{$\mathrm{N}_{2}$} & 400 & & 0.5 & & 8.0 & 6.1 & 20.7 & 0.027 & & \multirow{3}{*}{ [47] } \\
\hline & & 500 & & 0.5 & & 8.5 & 9.2 & 29.1 & 0.039 & & \\
\hline & & 600 & & 0.5 & & 9.0 & 6.2 & 29.8 & 0.038 & & \\
\hline Rice straw & oxygen-limited & 700 & & 2 & & & 58.97 & 369.26 & 0.23 & & \multirow{2}{*}{ [48] } \\
\hline \multirow{2}{*}{$\begin{array}{l}\text { Swine manure } \\
\text { Auricularia } \\
\text { auricula dreg }\end{array}$} & oxygen-limited & 700 & & 2 & & & 60.73 & 227.56 & 0.14 & & \\
\hline & & 400 & & 2 & & & 0.55 & 77.64 & 0.0612 & 4.837 & [49] \\
\hline Thalia dealbata & $\mathrm{N}_{2}$ & 500 & & 4 & & 10.09 & 22.0 & 7.1 & & & {$[50]$} \\
\hline Corn straw & $\mathrm{N}_{2}$ & 500 & & 1.5 & & & 41.0 & 32.85 & 0.0148 & 5.01 & [51] \\
\hline
\end{tabular}


Table 1. Cont.

\begin{tabular}{|c|c|c|c|c|c|c|c|c|c|c|c|}
\hline Raw Material & Atmosphere & $\begin{array}{c}\text { Temperature } \\
\left({ }^{\circ} \mathrm{C}\right)\end{array}$ & $\begin{array}{c}\text { Heating } \\
\text { Rate } \\
\left({ }^{\circ} \mathrm{C} / \mathrm{min}\right)\end{array}$ & $\begin{array}{l}\text { Residence } \\
\text { Time (h) }\end{array}$ & Yield (\%) & $\mathrm{pH}$ & $\begin{array}{c}\text { Ash } \\
\text { Content } \\
(\%)\end{array}$ & $\begin{array}{c}\text { Surface } \\
\text { Area } \\
\left(\mathrm{m}^{2} \cdot \mathrm{g}^{-1}\right)\end{array}$ & $\begin{array}{l}\text { Total Pore } \\
\text { Volume } \\
\left(\mathrm{cm}^{3} \cdot \mathrm{g}^{-1}\right)\end{array}$ & $\begin{array}{c}\text { Pore } \\
\text { Diameter } \\
(\mathrm{nm})\end{array}$ & Reference \\
\hline \multirow{2}{*}{ Pitch pine } & \multirow{2}{*}{ oxygen-free } & 400 & & $2 \mathrm{~s}$ & 33.5 & & 7.9 & 4.8 & & & \multirow{2}{*}{ [52] } \\
\hline & & 500 & & $2 \mathrm{~s}$ & 14.4 & & 7.7 & 175.4 & & & \\
\hline \multirow{2}{*}{$\begin{array}{l}\text { Wheat straw } \\
\text { Rice straw }\end{array}$} & $\mathrm{N}_{2}$ & 600 & 10 & 3 & & & 5.65 & 38.1 & 0.051 & 19.9 & \multirow{2}{*}{ [53] } \\
\hline & $\mathrm{N}_{2}$ & 600 & 10 & 3 & & & 0.03 & 27.4 & 0.040 & 15.8 & \\
\hline $\begin{array}{l}\text { Digested sugar } \\
\text { beet tailing }\end{array}$ & $\mathrm{N}_{2}$ & 600 & 10 & 2 & 45.5 & 9.95 & & 336.0 & & & \multirow[t]{2}{*}{ [54] } \\
\hline $\begin{array}{l}\text { Raw sugar beet } \\
\text { tailing }\end{array}$ & $\mathrm{N}_{2}$ & 600 & 10 & 2 & 36.3 & \multirow[t]{3}{*}{9.45} & & 2.6 & & & \\
\hline \multirow{2}{*}{ tea waste } & oxygen-limited & 700 & 7 & 2 & 28.35 & & 10.87 & 342.22 & 0.0219 & 1.756 & \multirow{2}{*}{ [55] } \\
\hline & $\mathrm{N}_{2}$ & 700 & 7 & 2 & 22.35 & & 11.60 & 421.31 & 0.0576 & 1.904 & \\
\hline
\end{tabular}




\subsection{Modification of Biochar}

In order to obtain biochar with superior properties, scholars studied the effects of different modification methods on biochar. Modification refers to the activation of the original biochar through physical and chemical methods, so as to achieve the desired purpose. The type of activator, soaking time, activation time, and activation temperature all affect the properties of biochar. Table 2 lists the biochar prepared from different modified.

\subsubsection{Chemical Oxidation}

Chemical oxidation refers to the oxidation of the biochar surface to increase the oxygen-containing functional groups such as $-\mathrm{OH},-\mathrm{COOH}$, etc., thereby its hydrophilicity is increased. At the same time, the pore size and structure of the biochar would be changed, and, finally, its adsorption capacity for the polar adsorbate would be enhanced. The commonly used oxidants are $\mathrm{HCl}, \mathrm{HNO}_{3}, \mathrm{H}_{2} \mathrm{O}_{2}$, $\mathrm{H}_{3} \mathrm{PO}_{4}$, etc. [56-60]. Although the specific surface area of biochar modified by $\mathrm{HCl}, \mathrm{HNO}_{3}$, and $\mathrm{H}_{2} \mathrm{O}_{2}$ has little difference, compared with biochar modified by $\mathrm{HCl}$, the biochar modified by $\mathrm{HNO}_{3}$ contains more acidic oxygen-containing functional groups [61] and has stronger adsorption capacity for $\mathrm{NH}_{3}-\mathrm{N}$. Compared with other acids, biochar modified by $\mathrm{H}_{3} \mathrm{PO}_{4}$ has more advantages in removing $\mathrm{Pb}$ pollution. The increased specific surface area and pore volume, as well as the role of phosphate precipitation, increase the biochar adsorption capacity of $\mathrm{Pb}$ [60].

\subsubsection{Chemical Reduction}

Chemical reduction is also known as alkali modification method. The reducing agent was used to reduce functional groups on the surface of biochar, so as to improve its non-polarity. Meanwhile, chemical modification also can improve porosity and specific surface area of biochar. Finally, adsorption capacity of biochar for pollutants is enhanced, especially for non-polar adsorbates. The commonly used reducing agents are $\mathrm{NaOH}$ [62], $\mathrm{KOH}$ [63], $\mathrm{NH}_{4} \mathrm{OH}$ [64], etc. [65]. Different reducing agents have different modification effects. In order to determine suitable modified biochar for improving adsorption capacity of volatile organic compounds (VOCs), Li et al. [64] used $\mathrm{NH}_{4} \mathrm{OH}, \mathrm{NaOH}, \mathrm{HNO}_{3}$, $\mathrm{H}_{2} \mathrm{SO}_{4}$, and $\mathrm{H}_{3} \mathrm{PO}_{4}$ to carry out chemical treatment on coconut shell-based carbon. The results showed that, compared with the poor adsorption capacity of acid-treated carbon, high adsorption capacity was obtained for alkali-treated carbon. The reason is that surface area and pore volume increased and total oxygen containing function groups were diminished when treated by alkalis, while acid treatment was the opposite. Pouretedal et al. [66] found that the process of biochar activation by $\mathrm{KOH}$ and $\mathrm{NaOH}$ is different. Atomic species, $\mathrm{K}$, formed in situ during $\mathrm{KOH}$ activation intercalates between the layers of the carbon crystallite, while there is hardly any evidence for the intercalation of $\mathrm{Na}$ with carbon.

\subsubsection{Metal Impregnation}

Metal impregnation refers to the adsorption of some heteroatoms or metal ions into the surface and pores of the biochar. On one hand, the specific surface area is increased, and on the other hand, metal ions are combined with the adsorbate to improve the adsorption performance. Common metal ions are iron [67], magnesium [68], silver [69], zinc [70], etc. Some scholars have combined the advantages of chemical reagents to achieve better adsorption performance. Lyu et al. [71] prepared a novel biochar material (CMC-FeS@biochar) via combining carboxymethyl cellulose (CMC) and iron sulfide (FeS), and demonstrated the effective sorbent of CMC-FeS@biochar composite for removal Cr(VI). 
Table 2. Preparation of different modified biochar.

\begin{tabular}{|c|c|c|c|c|c|}
\hline Raw Material & Reagent & Pollutant & Modification Method & Modification Effects & Reference \\
\hline $\begin{array}{l}\text { Bamboo } \\
\text { hardwoods }\end{array}$ & $\mathrm{NaOH}, \mathrm{CS}_{2}$ & $\mathrm{Cd}$ & $\begin{array}{l}\text { The composition of sulfur modified mixture } \\
\text { solution was obtained by stirring NaOH and } \\
\mathrm{CS}_{2} \text {. Biochar and sulfur modified mixture } \\
\text { solution stirred at } 45^{\circ} \mathrm{C} \text { for } 8 \mathrm{~h} \text {. }\end{array}$ & $\begin{array}{l}\text { Sulfur-modified biochar (S-BC) has more roughness, } \\
\text { with a more granular massive structure than that seen } \\
\text { on the pristine biochar. }\end{array}$ & [76] \\
\hline & $\mathrm{FeSO}_{4}$ & & $\begin{array}{l}\text { S-BC was added to } \mathrm{FeSO}_{4} \text { solution and then } \\
\text { stirred for } 16 \mathrm{~h} \text { with magnetic stirrer at } 40^{\circ} \mathrm{C} \text {, } \\
\text { and cooled slowly to room temperature and } \\
\text { filtered through } 0.45 \mu \mathrm{m} \text { filters. The feedstock } \\
\text { was oven-dried at } 40^{\circ} \mathrm{C} \text {. }\end{array}$ & $\begin{array}{l}\text { Successful impregnation of sulfur and iron onto the } \\
\text { SF-BC surface, and it showed various atomic } \\
\text { proportions of sulfur and iron, with biochar ranging } \\
\text { from } 0.48 \% \text { to } 4.66 \% \text { and } 0.44 \% \text { to } 22.25 \% \text {, } \\
\text { respectively. }\end{array}$ & \\
\hline Poplar chips & $\mathrm{AlCl}_{3}$ & $\mathrm{NO}_{3}^{-}, \mathrm{PO}_{4}^{3-}$ & $\begin{array}{l}\text { The poplar pieces were impregnated into } \mathrm{AlCl}_{3} \\
\text { solutions with different concentrations for } 6 \mathrm{~h} \text {. } \\
\text { The mixtures were dried at } 80^{\circ} \mathrm{C} \text { for } 48 \mathrm{~h} \text {. The } \\
\text { pretreated pristine poplars were pyrolyzed } \\
\text { under the } \mathrm{N}_{2} \text { atmosphere at } 550^{\circ} \mathrm{C} \text { with a } \\
\text { heating rate of } 5{ }^{\circ} \mathrm{C} / \mathrm{min} \text {, and the peak } \\
\text { temperature was maintained for } 2 \mathrm{~h} \text {. }\end{array}$ & $\begin{array}{l}\text { The biochar yield increased after modification with } \mathrm{Al} \text {. } \\
\text { The carbon content of the Al-modified biochar } \\
\text { significantly decreased compared with the pristine } \\
\text { biochar. The BET surface area significantly increased } \\
\text { with the } \mathrm{Al} \text { content of the biochar. } \mathrm{NO}_{3}{ }^{-} \text {and } \mathrm{PO}_{4}{ }^{3-} \\
\text { adsorptions significantly improved on the } \\
\text { Al-modified biochar. }\end{array}$ & [43] \\
\hline $\begin{array}{c}\text { Rice straw, } \\
\text { swine manure }\end{array}$ & $\mathrm{H}_{3} \mathrm{PO}_{4}$ & Tetracycline (TC) & $\begin{array}{l}\text { Biochars were immersed in } \mathrm{H}_{3} \mathrm{PO}_{4} \text { solution for } \\
24 \mathrm{~h} \text { at } 25^{\circ} \mathrm{C} \text {. Then, the } \mathrm{H}_{3} \mathrm{PO}_{4} \text { modified } \\
\text { biochars were washed by distilled water until } \\
\text { the } \mathrm{pH} \text { of supernatants was stable. Finally, the } \\
\text { supernatants were discarded and the biochars } \\
\text { were oven-dried overnight at } 105^{\circ} \mathrm{C} \text {. }\end{array}$ & $\begin{array}{l}\text { The } \mathrm{H}_{3} \mathrm{PO}_{4} \text { modification enhanced the surface area of } \\
\text { biochars produced from rice straw biochar (RC) and } \\
\text { swine manure biochar (SC). Compared with SC, } \\
\text { modified SC presented higher total pore, micropore } \\
\text { and mesopore volume by } 0.25 \text { to } 0.14,0.09 \text { to } 0.07,0.17 \\
\text { to } 0.07 \mathrm{~cm}^{3} \cdot \mathrm{g}^{-1} \text { ), but there was no change between RC } \\
\text { and } \mathrm{RCA} \text { modification. }\end{array}$ & [48] \\
\hline $\begin{array}{l}\text { Wheat straw, } \\
\text { cow manure }\end{array}$ & $\mathrm{HNO}_{3}$ & $\mathrm{U}(\mathrm{VI})$ & $\begin{array}{l}\text { Biochar powders were treated with } 300 \mathrm{~mL} 25 \% \\
\mathrm{HNO}_{3} \text { solution at } 90^{\circ} \mathrm{C} \text { for } 4 \mathrm{~h} \text {. The excess acid } \\
\text { was removed by centrifugation. All oxidized } \\
\text { biochar samples were washed with deionized } \\
\text { distilled water, freeze-dried, and milled to }<0.25 \\
\text { mm. }\end{array}$ & $\begin{array}{l}\text { Owing to the higher contents of surface COO groups } \\
\text { and more negative surface charge, the modified } \\
\text { biochar showed enhanced U(VI) adsorption ability } \\
\text { than the unmodified biochar. The maximum } \\
\text { adsorption capacity of U(VI) by the oxidized wheat } \\
\text { straw biochar showed an improvement of } 40 \text { times } \\
\text { relative to the untreated biochar. }\end{array}$ & [77] \\
\hline
\end{tabular}


Table 2. Cont.

\begin{tabular}{|c|c|c|c|c|c|}
\hline Raw Material & Reagent & Pollutant & Modification Method & Modification Effects & Reference \\
\hline $\begin{array}{l}\text { Auricularia } \\
\text { auricular dreg } \\
\text { (AAD) }\end{array}$ & $\begin{array}{l}\text { cetyltrimethyl } \\
\text { ammonium } \\
\text { bromide (CTAB) }\end{array}$ & $\mathrm{Cr}(\mathrm{VI})$ & $\begin{array}{l}\text { Mixed } 5 \mathrm{~g} \text { of dried AAD biochar with } 250 \mathrm{~mL} \text { of } \\
3.0 \% \mathrm{CTAB} \text { solution in } 25^{\circ} \mathrm{C} \text { for } 2 \mathrm{~h} \text {. Residual } \\
\mathrm{CTAB} \text { rinsed with deionized water and the } \\
\text { material was dried at } 70{ }^{\circ} \mathrm{C} \text { until the weight } \\
\text { remained constant. }\end{array}$ & $\begin{array}{l}\text { After modification, the surface area increased } 6.1 \% \\
\text { and the average pore diameter increased } 16.5 \% \text { ( } 77.64 \\
\mathrm{~m}^{2} / \mathrm{g} \text { and } 48.37 \mathrm{~A} \text { ). Moreover, the number of } \\
\text { mesoporous and micropores in unit area increased } \\
\text { obviously. The adsorption rate and quantity of } \\
\text { modified AAD biochar were } 6.4 \% \text { and } 8.0 \% \text { higher } \\
\text { than those of AAD biochar, respectively. }\end{array}$ & [49] \\
\hline Thalia dealbata & $\mathrm{MgCl}_{2}$ & $\begin{array}{l}\text { sulfamethoxazole } \\
\text { (SMX), Cd }\end{array}$ & $\begin{array}{l}\text { Thalia dealbata were soaked in } 100 \mathrm{~mL} 1 \mathrm{M} \\
\mathrm{MgCl}_{2} \text { solution, after } 0.5 \mathrm{~h} \text { mixing under } \\
\text { magnetic stirring, the pre-treated biomass was } \\
\text { then separated from the solution and pyrolyzed } \\
\text { at } 500^{\circ} \mathrm{C} \text {. }\end{array}$ & $\begin{array}{l}\text { The surface area of } \mathrm{MgCl}_{2} \text { modified biochar (BCM, } \\
110.6 \mathrm{~m}_{2} \cdot \mathrm{g}^{-1} \text { ) was higher than untreated biochar (BC, } \\
\left.7.1 \mathrm{~m}_{2} \cdot \mathrm{g}^{-1}\right) \text {. The addition of BCM increased the } \\
\text { sorption of SMX (by } 50.8-58.6 \% \text { ) and Cd (by } \\
24.2-25.6 \% \text { ) as compared with BC. In situ remediation } \\
\text { with } \mathrm{BCM} \text { decreased the mobility and bioavailability } \\
\text { of SMX and Cd in sediments. }\end{array}$ & [50] \\
\hline Corn straw & $\mathrm{Na}_{2} \mathrm{~S}$ and $\mathrm{KOH}$ & $\mathrm{Hg}(\mathrm{II})$, atrazine & $\begin{array}{l}\text { Biochar were mixed with } 500 \mathrm{~mL} \text { of } 2 \mathrm{M} \mathrm{Na}_{2} \mathrm{~S} \text { or } \\
2 \mathrm{M} \mathrm{KOH} \text { solution and stirred for } 4 \mathrm{~h} \text {. The } \\
\text { suspension was then filtered and washed with } \\
\text { deionized water for several times until the } \mathrm{pH} \text { of } \\
\text { the filtrate was nearly } 7 \text {. The washed biochar } \\
\text { was dried overnight in an oven at } 105^{\circ} \mathrm{C} \text {. }\end{array}$ & $\begin{array}{l}\text { Sulfur content significantly increased by } 101.29 \% \\
\text { under } \mathrm{Na}_{2} \mathrm{~S} \text { modification. Compared to untreated } \\
\text { biochar }\left(\mathrm{BC}, 32.85 \mathrm{~m}_{2} \cdot \mathrm{g}^{-1}\right) \text {, chemical modification } \\
\text { increased the BET surface area which was } 55.58 \text { and } \\
59.23 \mathrm{~m}_{2} \cdot \mathrm{g}^{-1} \text { for } \mathrm{Na}_{2} \mathrm{~S} \text { modified biochar (BS), KOH } \\
\text { modified biochar (BK), respectively. In comparison to } \\
\mathrm{BC} \text {, the sorption capacity of BS and BK for } \mathrm{Hg} \text { (II) } \\
\text { increased by } 76.95 \%, 32.12 \% \text {, while that for atrazine } \\
\text { increased by } 38.66 \%, 46.39 \% \text {, respectively. }\end{array}$ & [51] \\
\hline Coconut shell & $\mathrm{HCl}+$ ultrasonication & $\mathrm{Cd}, \mathrm{Ni}$ and $\mathrm{Zn}$ & $\begin{array}{l}5 \mathrm{~g} \text { of CS biochar and } 250 \mathrm{~mL} \text { of } 1 \mathrm{M} \mathrm{HCl} \text { were } \\
\text { mixed in beaker and ultrasonicated for } 3 \mathrm{~h} \text { with } \\
\text { interval stirring. Then, the material was filtered, } \\
\text { washed, and dried to constant weight. }\end{array}$ & $\begin{array}{l}\text { Modified coconut shell biochar (MCSB) improved } \\
\text { surface functional groups and microcosmic pore } \\
\text { structure of pristine biochar (CSB). }\end{array}$ & [78] \\
\hline Dairy manure & $\mathrm{NaOH}$ & $\mathrm{Pb}$ and $\mathrm{Cd}$ & $\begin{array}{l}\text { Biochar and } 2 \mathrm{M} \mathrm{NaOH} \text { were thoroughly mixed } \\
\text { with a solid-liquid ratio of } 1: 5 \text { and then were } \\
\text { re-suspended for } 12 \mathrm{~h} \text { with a speed of } 30 \mathrm{r} \text { min } \\
\text { at } \\
\text { at } 65^{\circ} \mathrm{C} \text {. After that, the mixture was filtered, and } \\
\text { the precipitate was collected and rinsed with } \\
\text { deionized. Finally, material was dried at } 105^{\circ} \mathrm{C} \text {. }\end{array}$ & $\begin{array}{l}\text { The } \mathrm{NaOH} \text { treatment increased the specific surface } \\
\text { area, ion-exchange capacity, and the number of } \\
\text { oxygen-containing functional groups of biochar. The } \\
\text { adsorption capacities of biochar for } \mathrm{Pb} \text { and } \mathrm{Cd} \\
\text { increased after modification. The highest sorption } \\
\text { capacities were } 175.53 \text { and } 68.08 \mathrm{mg} \cdot \mathrm{g}^{-1} \text {, for } \mathrm{Pb} \text { and } \\
\mathrm{Cd} \text {, respectively. }\end{array}$ & [79] \\
\hline
\end{tabular}




\subsubsection{Other Modification Methods}

In addition to the above three modification methods, modification methods such as low-temperature plasma [72,73], organic matter grafting [74], and ozone oxidation [32] have also been studied. Low-temperature plasma modification means that plasmas generated by glow, microwave, and corona were collided with $\mathrm{C}=\mathrm{C}$ on the surface of biochar, and plasmas were oxidized to the oxygen-containing functional group, and enhanced the polarity of biochar [75]. However, such methods have not been widely used due to high cost and complicated operation.

\section{Removal Mechanism of Major Pollutants by Biochar}

The remediation mechanisms of soil pollution by biochar include ion exchange, physical adsorption, electrostatic interaction, precipitation, and complexation [9].

\subsection{Ion Exchange}

Ion exchange means the process that acidic oxygen-containing functional groups on the surface of biochar, such as carboxyl groups, carbonyl groups, and hydroxyl groups, can ionize $\mathrm{H}^{+}$or surface base ions such as $\mathrm{Na}^{+}, \mathrm{K}^{+}, \mathrm{Ca}^{2+}, \mathrm{Mg}^{2+}$, etc., to exchange with heavy metal ions or cationic organic pollutants [80].

\subsection{Physical Adsorption}

Physical adsorption means that biochar utilizes its surface characteristics, namely porosity and large specific surface area, so that pollutants such as heavy metals or organic substances could be adsorbed on its surface or diffused into the micropores. The diameter of the heavy metal ions is smaller than the average pore diameter of the biochar. Generally, the smaller the diameter of the heavy metal, the more the pores penetrate into the pores of the biochar, thereby increasing the adsorption capacity $[81,82]$. The intensity of physical adsorption is closely related to the properties and specific surface area of biochar, the properties and concentration of pollutants, and the temperature during adsorption process. Physical adsorption kinetics is usually fitted by pseudo-first-order and pseudo-second-order kinetic models $[83,84]$. Physical adsorption can be either single-layer adsorption or multi-layer adsorption, which is usually fitted by Langmuir and Freundlich model $[85,86]$.

\subsection{Electrostatic Interaction}

Electrostatic interaction refers to the electrostatic adsorption between the surface charge of biochar and heavy metal ions. When the $\mathrm{pH}$ value of solution is greater than the charge point of biochar $\left(\mathrm{pH}_{\mathrm{pzc}}\right)$, the negative charge on the surface of biochar and the heavy metal with positive charge causes electrostatic adsorption. Heavy metal ions with positive charge on the surface of biochar combine with oxygen-containing functional groups such as carboxyl, carbonyl, and hydroxyl [87-91].

\subsection{Precipitation}

Mineral components in biochar, such as $\mathrm{CO}_{3}{ }^{2-}, \mathrm{PO}_{4}{ }^{3-}, \mathrm{SiO}_{3}{ }^{4-}, \mathrm{Cl}^{-}, \mathrm{SO}_{4}{ }^{2-}, \mathrm{SO}_{3}{ }^{2-}$, and $\mathrm{OH}^{-}$, combine with heavy metal ions to form water insoluble substances such as metal oxides, metal phosphates, and metal carbonates, which promote the adsorption and immobilization of heavy metals. $\mathrm{Xu}$ et al. [92] believed that the adsorption of $\mathrm{Cu}, \mathrm{Zn}$, and $\mathrm{Cd}$ by fertilizer biochar was mainly attributed to the precipitation of $\mathrm{CO}_{3}{ }^{2-}$ and $\mathrm{PO}_{4}{ }^{3-}$, while the electron surface complexation via -OH groups or delocalized $\pi$ was less.

\subsection{Complexation}

Complexation refers to the interaction between oxygen-containing functional groups on the surface of biochar and heavy metals to form complexes, which could be fixed. Qian et al. [93] studied the aluminum phytotoxicity of cow manure biochar to wheat and concluded that the adsorption of 
aluminum by biochar was mainly through the complexation of carboxyl group with $[\mathrm{Al}(\mathrm{OH})]^{2+}$ and its monomer surface, rather than through the electrostatic attraction of $\mathrm{Al}^{3+}$ with negative charge sites. Jia et al. [94] believed that the adsorption of oxytetracycline by biochar was mainly mediated by $\pi-\pi$ interaction and metal bridge, with surface complexation as the main factor, and cationic exchange might exist.

In the process of adsorption, it is often not a single mechanism, but a combination of multiple adsorption mechanisms. Table 3 summarizes the adsorption mechanism of biochar for pollution restoration. 
Table 3. Adsorption mechanism of biochar for pollution remediation.

\begin{tabular}{|c|c|c|c|}
\hline Raw Material & Pollutant & Mechanism & Reference \\
\hline Municipal sewage sludge & $\mathrm{Cd}$ & $\begin{array}{l}\text { Surface precipitation under alkaline conditions and exchange of exchangeable cations } \\
\text { with Cd. }\end{array}$ & [95] \\
\hline Fertilizer & $\mathrm{Cu}, \mathrm{Zn}$ and $\mathrm{Cd}$ & $\begin{array}{l}\text { Precipitate from } \mathrm{CO}_{3}{ }^{2-}, \mathrm{PO}_{4}{ }^{3-} \text { on the surface of the biochar, partially by surface } \\
\text { complexing with -OH group or delocalized } \pi \text { electron. }\end{array}$ & [92] \\
\hline $\begin{array}{l}\text { Rice husk loaded with } \\
\text { manganese oxide }\end{array}$ & $\mathrm{Pb}$ & $\begin{array}{l}\text { Oxide spherical complexes and biochar surface oxygen complexes; the } \pi \text {-band electron } \\
\text { density of graphene-based carbon in the } \pi \text {-electron cloud system reduces vacancies on } \\
\text { the surface of biochar, thereby adsorbing } \mathrm{Pb}^{2+} \text {. }\end{array}$ & [96] \\
\hline Wheat straw, pine needles & $\mathrm{Zn}$ & $\begin{array}{l}\text { The components of -OH, } \mathrm{CO}_{3}^{2-} \text {, and } \mathrm{Si} \text { in biochar can form precipitates with } \mathrm{Zn}^{2+} \text {. } \\
\text { Electron-donor-acceptor (EDA) interaction with } \mathrm{pH}<2.0 \text {, also forms charge-assisted }\end{array}$ & [97] \\
\hline Bamboo, eucalyptus & chloramphenicol & $\begin{array}{l}\text { hydrogen bonds (CAHB) and hydrogen bonds at } \mathrm{pH} 4.0-4.5 \text {, and interaction with } \\
\mathrm{CAHB} \text { and EDA at } \mathrm{pH}>7.0 \text {. }\end{array}$ & [98] \\
\hline Corn straw & $\mathrm{Hg}(\mathrm{II})$, atrazine & $\begin{array}{l}\text { After } \mathrm{Na}_{2} \mathrm{~S} \text { modification, sulfur impregnated onto the biochar reacted with } \mathrm{Hg}(\mathrm{II}) \text { to } \\
\text { form } \mathrm{HgS} \text {, which greatly facilitated the sorption of } \mathrm{Hg} \text { (II). Formation of surface } \\
\text { complexes between } \mathrm{Hg}(\mathrm{II}) \text { and the functional groups of sorbent, such as phenolic } \\
\text { hydroxyl, carboxylic groups. These oxygen-containing functional groups exchanged } \\
\text { ion with } \mathrm{Hg}(\mathrm{II}) \text {. The electrostatic and EDA interaction also participated in } \mathrm{Hg}(\mathrm{II}) \\
\text { sorption. }\end{array}$ & [51] \\
\hline Dairy manure & $\mathrm{Pb}$ and $\mathrm{Cd}$ & $\begin{array}{l}\text { Because of the easy hydrolysis of } \mathrm{Pb} \text { at low } \mathrm{pH} \text {, biochar has a higher affinity for } \mathrm{Pb} \text { than } \\
\mathrm{Cd} \text {. Besides, precipitation as carbonate minerals }\left(2 \mathrm{PbCO}_{3} \cdot \mathrm{Pb}(\mathrm{OH})_{2} \text { and } \mathrm{CdCO}_{3}\right) \text { and } \\
\text { complexation with functional groups such as carboxyl and hydroxyl, were also } \\
\text { important for adsorption of } \mathrm{Pb} \text { and } \mathrm{Cd} \text { by biochar. }\end{array}$ & [79] \\
\hline Rice straw, swine manure & Tetracycline (TC) & $\begin{array}{l}\text { The H-bonding, electrostatic attraction and EDA interaction might be the primary } \\
\text { mechanism during adsorption process. }\end{array}$ & [48] \\
\hline Sugar beet tailing (SBT) & $\mathrm{Cr}(\mathrm{VI})$ & $\begin{array}{l}\text { First, SBT biochar reduced } \mathrm{Cr}(\mathrm{VI}) \text { to } \mathrm{Cr}(\mathrm{III}) \text { by electrostatic adsorption. Second, with the } \\
\text { participation of hydrogen ions and the electron donors from SBT biochar, } \mathrm{Cr}(\mathrm{VI}) \text { was } \\
\text { reduced to } \mathrm{Cr}(\mathrm{III}) \text {. Then, the function groups on the SBT biochar complexed with } \\
\mathrm{Cr}(\mathrm{III}) \text {. }\end{array}$ & [99] \\
\hline Empty fruit bunch, rice husk & $\mathrm{As}(\mathrm{III}), \mathrm{As}(\mathrm{V})$ & $\begin{array}{l}\text { Surface complexes were formed between } \mathrm{As}(\mathrm{III}) \text { and } \mathrm{As}(\mathrm{V}) \text { and the functional groups } \\
\text { (hydroxyl, carboxyl, and C-O ester of alcohols) of the two biochars. }\end{array}$ & {$[100,101]$} \\
\hline Bamboo biomass & $\begin{array}{l}\text { Sulfathiazole, sulfamethoxazole, } \\
\text { sulfamethazine }\end{array}$ & $\begin{array}{l}\text { The sorption of neutral sulfonamide species occurred mainly due to } \mathrm{H} \text {-bonds followed } \\
\text { by EDA, and by Lewis acid-base interaction. EDA was the main mechanism for the } \\
\text { sorption of positive sulfonamides species. The sorption of negative species was mainly } \\
\text { due to proton exchange with water forming negative CAHB, followed by the } \\
\text { neutralization of }-\mathrm{OH} \text { groups by } \mathrm{H}^{+} \text {released from functionalized biochar surface, and } \\
\pi-\pi \text { electron-acceptor-acceptor (EAA) interaction. }\end{array}$ & [102] \\
\hline
\end{tabular}




\section{Application of Biochar in Soil Remediation}

\subsection{Removal of Heavy Metals}

The removal of heavy metals by biochar is mainly reflected in two aspects: One is the adsorption of heavy metals in the pores of biochar to reduce the residual amount in the soil; the other is the ion exchange or redox reaction between the effective components in biochar and heavy metal ions to stabilize the formation of heavy metal precipitates or to reduce toxicity by transforming them into low-valent states.

Boostani et al. [103] investigated the effect of sheep and earthworm manure biochars on $\mathrm{Pb}$ immobilization in a contaminated calcareous soil. The addition of biochars resulted in a significant increase in the $\mathrm{Pb}$ content in the residual state, which reduced the $\mathrm{Pb}$ activity in the soil. Chen et al. [79] studied the adsorption mechanisms for removal $\mathrm{Pb}$ and $\mathrm{Cd}$ with dairy manure biochar. The extractable $\mathrm{Pb}$ and $\mathrm{Cd}$ contents decreased significantly and were converted to the precipitation as carbonate minerals. However, it may also be due to the lack of selective adsorption capability of biochar, which adsorbs nitrogen in the soil, resulting in a decrease in soil nutrients [104]. When the soil pollution is contaminated by complex heavy metals, although biochar reduces the concentration of extractable heavy metals, biochar has different adsorption effects on different heavy metals due to competitive adsorption. Yang et al. [105] showed that straw and bamboo biochar are more effective than $\mathrm{Zn}$ in reducing extractable $\mathrm{Cu}$ and $\mathrm{Pb}$. Zhou et al. [106] also reached a similar conclusion. In the single metal adsorption test, the adsorption capacity of sludge biochar to $\mathrm{Zn}$ was the largest, while in the polymetallic adsorption test, the adsorption capacity of $\mathrm{Mn}, \mathrm{Cu}$, and $\mathrm{Zn}$ decreased, but the adsorption capacity of $\mathrm{Cr}$ increased. Table 4 shows the research on removing heavy metals in soil by using biochar in the past two years. 
Table 4. Study on the application of biochar to the remediation of heavy metal pollution in soil.

\begin{tabular}{|c|c|c|c|c|}
\hline Raw Material & Tested Soil & Pollutant & Remediation Effect & Reference \\
\hline $\begin{array}{l}\text { Bamboo, rice straw, and } \\
\text { Chinese walnut shell }\end{array}$ & $\begin{array}{l}\text { industrial } \\
\text { contaminated soil }\end{array}$ & $\mathrm{Cu}$ & $\begin{array}{l}\text { Cu uptake in roots was reduced by } 15 \%, 35 \% \text {, and } 26 \% \text {, respectively. Rice straw } \\
\text { biochar reduced solubility of } \mathrm{Cu} \text { and } \mathrm{Pb} \text {. }\end{array}$ & [107] \\
\hline Sewage sludge & Brazil soil & $\mathrm{Cd}, \mathrm{Pb}$, and $\mathrm{Zn}$ & $\begin{array}{l}\text { Biochar reduced the concentration and bioavailable levels of } \mathrm{Cd}, \mathrm{Pb} \text {, and } \mathrm{Zn} \text { of } \\
\text { in the leachates. }\end{array}$ & [108] \\
\hline Poultry litter & $\begin{array}{l}\text { paddy soil near } \mathrm{Zn} \\
\text { and } \mathrm{Pb} \text { mines }\end{array}$ & $\mathrm{Cd}, \mathrm{Cu}, \mathrm{Zn}, \mathrm{Pb}$ & $\begin{array}{l}\text { Acid-soluble Cd in soils amended with poultry litter biochar was } 8 \% \text { to } 10 \% \\
\text { lower than in the control polluted soil. }\end{array}$ & [109] \\
\hline Wheat straw & acid soil & $\mathrm{Cd}$ and $\mathrm{Cu}$ & $\begin{array}{l}\text { Cu concentration in wheat roots was reduced most efficiently to } 40.9 \% \text { by } \\
\text { biochar. Available Cd and Cu in soil added biochar decreased } 18.8 \% \text { and } 18.6 \% \text {. }\end{array}$ & [110] \\
\hline Rice husk & $\begin{array}{l}\text { saturated soil, dryland } \\
\text { soil }\end{array}$ & $\mathrm{Cd}$ & $\begin{array}{l}\text { The adsorption of } C d \text { on saturated soil increased by } 21-41 \% \text {, and that on } \\
\text { dryland soil increased by } 38-54 \% \text {. }\end{array}$ & [111] \\
\hline Gliricidia sepium & shooting range soil & $\mathrm{Pb}, \mathrm{Cu}$ & $\begin{array}{l}\text { The addition of biochar to the soil reduced the dissolution rates of } \mathrm{Pb} \text { and } \mathrm{Cu} \text { by } \\
10.0-99.5 \% \text { and } 15.6-99.5 \% \text {, respectively, and was able to fix } \mathrm{Pb} \text { and } \mathrm{Cu} \text { released } \\
\text { by protons and ligands in the soil. }\end{array}$ & [112] \\
\hline $\begin{array}{l}\text { Poultry manure, cow manure, } \\
\text { and sheep manure }\end{array}$ & farmland soil & $\mathrm{Cr}(\mathrm{VI})$ & $\begin{array}{l}\text { Poultry manure decreased61.54 } \mathrm{mg} \cdot \mathrm{kg}^{-1} \mathrm{Cr}(\mathrm{VI}) \text { in acidic soil and } 73.93 \\
\mathrm{mg} \cdot \mathrm{kg}^{-1} \mathrm{Cr}(\mathrm{VI}) \text { in alkaline soil. Cow and Sheep manure decreased by } 66.61 \\
58.67 \text {, and } 57.81,68.15 \mathrm{mg} \cdot \mathrm{kg}^{-1} \mathrm{Cr}(\mathrm{VI}) \text { in acidic and alkaline soil, respectively. }\end{array}$ & [113] \\
\hline
\end{tabular}


In order to achieve better remediation effect, scholars gradually carry out research on the modification of biochar. Modification refers to the activation of the original biochar through physical and chemical methods, so as to achieve the desired purpose. The modification methods of surface structure characteristics are generally divided into physical method, chemical method, and combined method [65]. In the early stage, Monser et al. [114] modified activated carbon with sodium dodecyl sulfonate to reduce the heavy metal content in phosphoric acid and reduce the content of cadmium and chromium. Scholars have modified biochar similarly to activated carbon, mainly by chemical modification, through adding acid, alkali, oxidants, and supporting various metal oxides to aminated, acidify, and alkalinize biochar. Oxidation, etc., increase the surface oxygen-containing functional groups, thereby achieving a good repair effect. Studies on the adsorption effect of modified biochar are dominated by heavy metals, followed by organics, and most of them are adsorption of heavy metals in aqueous solution. Table 5 provides a summary of studies on soil pollution remediation by various types of modified biochar in recent years. 
Table 5. The remediation of soil pollution by various types of modified biochar.

\begin{tabular}{|c|c|c|c|c|c|}
\hline Raw Material & Modification & Pollutant & Tested Soil & Remediation Effect & Reference \\
\hline Bamboo hardwoods & sulfur-iron & $\mathrm{Cr}$ & plant farmland & $\begin{array}{l}\text { Sulfur-modified biochar (S-BC) and sulfur-iron modified } \\
\text { biochar (SF-BC) addition increased the content of soil organic } \\
\text { matter, alpha diversity indices, and changed soil bacterial } \\
\text { community structure. The exchangeable Cd in soil was } \\
\text { decreased by } 12.54 \%, 29.71 \%, 18.53 \% \text { under the treatments of } \\
\text { BC, S-BC, SF-BC, respectively. }\end{array}$ & [76] \\
\hline $\begin{array}{l}\text { Poultry, cow, sheep } \\
\text { manure }\end{array}$ & Chitosan, ZVI & $\mathrm{Cr}$ & $\begin{array}{l}\text { uncontaminated } \\
\text { surface soil }\end{array}$ & $\begin{array}{l}\text { Modified sheep manure biochar reduced } \mathrm{Cr}(\mathrm{VI}) \text { by } 55 \% \text {, and } \\
\text { poultry manure modified biochar reduced } \mathrm{Cr}(\mathrm{VI}) \text { by } 48 \% \text {. } \\
\text { Modified biochar decreased the content of available As, }\end{array}$ & [113] \\
\hline corn straw & Fe-Mn & As & paddy soil & $\begin{array}{l}\text { increased the residual, amorphous hydrous oxide-bound, and } \\
\text { crystalline hydrous oxide-bound As forms. }\end{array}$ & [115] \\
\hline $\begin{array}{l}\text { Eucalyptus wood and } \\
\text { poultry litter }\end{array}$ & iron & $\mathrm{Cd}, \mathrm{Cu}, \mathrm{Zn}, \mathrm{Pb}$ & $\begin{array}{l}\text { paddy soil near } \mathrm{Zn} \\
\text { and } \mathrm{Pb} \text { mines }\end{array}$ & $\begin{array}{l}\text { Acid-soluble Cd, } \mathrm{Zn}, \mathrm{Cu} \text { in soils amended with poultry litter } \\
\text { biochar (PLB) was } 8 \% \text { to } 10 \%, 27 \% \text { to } 29 \%, 59 \% \text { to } 63 \% \text {, } \\
\text { respectively, lower than in the control polluted soil. Plant } \\
\text { biomass increased by } 32 \% \text { in the treatments containing } \\
\text { magnetic PLB. }\end{array}$ & [109] \\
\hline Coconut shell & $\mathrm{HCl}+$ ultrasonication & $\mathrm{Cd}, \mathrm{Ni}$, and $\mathrm{Zn}$ & $\begin{array}{l}\text { topsoil of paddy } \\
\text { fields }\end{array}$ & $\begin{array}{l}\text { In groups with } 5 \% \text { MCSB addition, the acid soluble } \mathrm{Cd} \text {, Ni and } \\
\mathrm{Zn} \text { decreased by } 30.1 \%, 57.2 \% \text {, and } 12.7 \% \text {, respectively. }\end{array}$ & [78] \\
\hline Rice husk & Sulfur & $\mathrm{Hg}$ & $\begin{array}{l}\mathrm{Hg} \text { contaminated } \\
\text { soil }\end{array}$ & $\begin{array}{l}\text { Modification increased the } \mathrm{Hg}^{2+} \text { adsorptive capacity of biochar } \\
\text { by } 73 \% \text {, to } 67.11 \mathrm{mg} \cdot \mathrm{g}^{-1} \text {. And freely available } \mathrm{Hg} \text { in TCLP } \\
\text { (toxicity characterization leaching procedure) leachates by } \\
95.4 \%, 97.4 \% \text {, and } 99.3 \% \text {, respectively, compared to untreated } \\
\text { soil. }\end{array}$ & [116] \\
\hline Corn straw & $\mathrm{MnO}$ & As & red soil & $\begin{array}{l}\text { Modified biochar (MBC) in red soil had a much greater } \\
\text { sorption capacity for As(III) than pristine biochar, although } \\
\text { both enhanced the sorption of As(III) in red soil. }\end{array}$ & [117] \\
\hline
\end{tabular}




\subsection{Removal of Persistent Organic Pollutants (POPS)}

The persistent organochlorine pesticides in farmland soils in are still seriously polluted, and the polycyclic aromatic hydrocarbon pollution caused by sewage irrigation cannot be ignored. Biochar has a strong adsorption capacity for organic pollutants, and the process can be understood as the accumulation and collection of organic pollutants on biochar. Table 6 shows the research on the removal of POPs from soil by using biochar in the past two years. 
Table 6. Study on the application of biochar to remove persistent organic pollutants (POPs) in soil.

\begin{tabular}{|c|c|c|c|c|}
\hline Raw Material & Tested Soil & Pollutants & Remediation Effect & Reference \\
\hline Fir wood chips & rice soil & 2,4-dichlorophenol, phenanthrene & $\begin{array}{l}\text { Reduced the degradation and mineralization of both pollutants. Increased the } \\
\text { accumulation of their metabolites in soil. }\end{array}$ & [118] \\
\hline $\begin{array}{l}\text { Mixed wood shavings } \\
\text { Rice husk }\end{array}$ & $\begin{array}{l}\text { loamy } \\
\text { agricultural soil }\end{array}$ & $\begin{array}{l}\text { Pyrene, polychlorinated biphenyl and } \\
\text { dichlorodiphenyldichloroethylene } \\
\text { (DDE) }\end{array}$ & $\begin{array}{l}\text { At the biochar dose of } 10 \% \text {, bioavailability and accessibility by } 37 \% \text { and } 41 \% \text {, } \\
\text { respectively, compared to unamended soil. }\end{array}$ & [119] \\
\hline Rice hull & $\begin{array}{l}\text { loamy clay, sandy } \\
\text { loam, clay loam }\end{array}$ & oxyfluorfen & $\begin{array}{l}\text { Oxyfluorfen degraded faster in biochar amended soil than in unamended soil. } \\
\text { Biochar decreased the oxyfluorfen uptake by soybean plants by } 18-63 \% \text {, and the } \\
\text { adsorption capacity of oxyfluorfen by soybean decreased. }\end{array}$ & [120] \\
\hline Orchard pruning biomass & vineyard & PAHs & $\begin{array}{l}\text { During the investigated period, PAH concentrations decreased with time and the } \\
\text { change resulted more intense for light PAHs. The soil properties (TOC, pH, CEC, } \\
\text { bulk density) were modified after two consecutive applications }\end{array}$ & [121] \\
\hline Corn straw and bamboo & $\begin{array}{l}\text { soil contaminated } \\
\text { with PAHs }\end{array}$ & PAHs & $\begin{array}{l}\text { The bioaccumulation of PAHs in rice roots was reduced, especially high molecular } \\
\text { weight PAHs. The total and bioavailable concentration of PAHs in the soil treated } \\
\text { with corn straw biochar were both lower than that of the control group. }\end{array}$ & [100] \\
\hline
\end{tabular}


Koltowski et al. [122] studied the removal effect of PAHs in soil by microwave, $\mathrm{CO}_{2}$, and $\mathrm{H}_{2} \mathrm{O}$ activation of willow biochar. The results showed that the biochar samples with the best effect after activation reduced the concentration of PAHs dissolved in the coal plant soil (near cooking plant battery) and bitumen plant soil from 153 to $22 \mathrm{ng} / \mathrm{L}$ and 174 to $24 \mathrm{ng} / \mathrm{L}$, respectively, and the PAHs concentration decreased by $86 \%$. The concentration of PAHs dissolved in the asphalt soil (from an industrial waste deposit) decreased from 52 to $16 \mathrm{ng} / \mathrm{L}$, and bioacceptable PAHs reduced to almost zero. Zhang et al. [123] applied biochar from corn straw and pig manure to black soil containing thiacloprid, and explored the adsorption and degradation process of thiacloprid. The results showed that the biochar changed the microbial community of soil by changing the physicochemical properties of the soil, thus promoting the biodegradation of thiacloprid.

In general, biochar can enhance the adsorption capacity of soil for organic pollutants, reduce their activities of desorption and flow in the soil, and bioavailability in soil pore water, provide essential nutrients to improve soil microbial activity, and improve soil physical and chemical properties, etc. [124].

\subsection{Amelioration of Soil}

The improvement of soil by biochar is mainly reflected in the improvement of soil organic matter content, the increase of nitrogen, potassium, and other nutrients contents and utilization rate, and the improvement of soil erosion and acid soil.

The application of biochar can significantly increase the content of soil organic matter, alkali-hydrolyzed nitrogen, ammonium nitrogen, and available potassium, but the more biochar added is not better. Excessive application of biochar can inhibit the content of nutrients. Bayabil et al. [125] mixed acacia, croton, and eucalyptus charcoal into the soil in a basin of the Ethiopian plateau, and found through laboratory and field experiments that it had a good improvement on the water conservancy characteristics of degraded soil, so as to reduce runoff and erosion. Biochar is mostly alkaline, which can improve the utilization and absorption of nutrients in rice by increasing the $\mathrm{pH}$ value of acid soil [126]. In addition, the effect of biochar on soil cation exchange capacity was significant. Agegnehu et al. [127] found that biochar, compost, and their compounds significantly improved the availability and use of plant nutrients: Soil organic carbon, moisture content, CEC, and peanut yield all increased, and greenhouse gas emissions decreased.

Nitrogen is an essential nutrient for plant growth. The application of nitrogen fertilizer could replenish soil nitrogen and maintain land productivity. However, over-application will cause a large loss of soil nitrogen, reduce the efficiency and utilization of nitrogen fertilizer, and aggravate the eutrophication pollution degree of surrounding water environment such as rivers and lakes. The inhibition of nitrogen and phosphorus leaching by biochar is considered as follows: Biochar changed the microbial-mediated reactions in soil nitrogen and phosphorus cycles, namely $\mathrm{N}_{2}$ fixation, nitrogen and phosphorus mineralization, nitrification, ammonia volatilization, and denitrification. At the same time, biochar provided a reactive surface in which nitrogen and phosphorus ions remain in the soil microbial biomass and exchange sites, both of which regulate crop nitrogen and phosphorus availability [128].

\subsection{Potential Risk of Biochar}

Although biochar has great advantages in remediation of soil pollution, improvement of soil quality, increase of crop yield, and reduction of greenhouse gas emissions, these studies are all short-term and the long-term effects of biochar on soil are still ambiguous. Therefore, in order to make better use of biochar and reduce its possible risks, the long-term effects and risk assessment of biochar on soil should be paid more attention. Studies have shown that, although the application of biochar improved soil quality and crop yield, biochar reduced the efficacy of herbicide and increased weed growth by $200 \%$ [129]. The reduction of herbicide efficacy must increase the use of herbicide, which may increase the residual concentration of herbicide in the soil and cause more serious pollution 
to the soil. In addition, biochar, which is mostly prepared from crop waste, may contain heavy metals on its own and could release pollutants if it gets into the soil. Due to the weathering and aging, biochar would undergo physical, chemical, and biological degradation. Finally, it would form colloids, nanoparticles, and smaller fragments that alter the microbial community in the soil. However, the interaction between these components of biochar and soil, the internal mechanism of microbial transformation and geochemical circulation still need to be further studied [130].

\section{Conclusions}

In this paper, the effects of preparation, process parameters, and modification of biochar on its physicochemical properties were reviewed. The mechanism of biochar remediation for soil pollution was summarized, the application status of biochar in soil remediation was analyzed, and the research articles on the removal of heavy metals and organic pollutants by biochar in the past two years were listed; lastly, the possible risks in the application of biochar were proposed. The application of biochar in soil remediation can not only reduce the damage of soil wastes to the atmosphere and water environment, but also remove the pollutants in the soil and improve the soil quality. In addition, biochar has advantages in dealing with water pollution and reducing greenhouse gas emissions, so the research on the application of biochar is of great significance to sustainable development.

At present, the following problems still exist in the application of biochar: (i) Although studies are on the same type of biochar to repair the same kind of pollution, the mechanism of action, adsorption kinetics, thermodynamics, etc., are different; (ii) in terms of the characterization of biochar, there is no unified standard, which is difficult to compare; (iii) the number of indoor tests is much more than of field outdoor tests, which results in the incomplete considered factors and difficult practical application; (iv) the research on the mechanism of biochar on compound pollution is not thorough enough; (v) the study on the long-term effects and negative effects of biochar is not well studied; and (vi) there is little research about life cycle assessment of biochar and the overall economic value of biochar applications is not clearly enough.

Author Contributions: Conceptualization, X.Y. and S.Z.; methodology, L.L.; writing-original draft preparation, X.Y.; writing—review and editing, X.Y. and S.Z.; supervision, M.J., L.L.

Funding: This research was funded by National Natural Science Foundation of China, grant number 51708301; 2017 Science and Technology Demonstration Project of Industrial Integration and Development, Tianjin, China, grant number 17ZXYENC00100; Young Elite Scientists Sponsorship Program by Tianjin, grant number TJSQNTJ-2018-06; Natural Science Foundation of Tianjin, China, grant number 17JCZDJC39500.

Acknowledgments: This research was also supported by the Fundamental Research Funds for the Central Universities. The authors appreciate the financial support and thank the editor and reviewers for their very useful suggestions and comments.

Conflicts of Interest: The authors declare no conflict of interest.

\section{References}

1. Li, Z.; Ma, Z.; Van Der Kuijp, T.J.; Yuan, Z.; Huang, L. A review of soil heavy metal pollution from mines in China: Pollution and health risk assessment. Sci. Total Environ. 2014, 468, 843-853. [CrossRef]

2. Renella, G.; Landi, L.; Nannipieri, P. Degradation of low molecular weight organic acids complexed with heavy metals in soil. Geoderma 2004, 122, 311-315. [CrossRef]

3. Yang, H.; Huang, X.; Thompson, J.R.; Flower, R.J. Soil Pollution: Urban Brownfields. Science 2014, 344, 691-692. [CrossRef]

4. Tang, X.; Shen, C.; Shi, D.; Cheema, S.A.; Khan, M.I.; Zhang, C.; Chen, Y. Heavy metal and persistent organic compound contamination in soil from Wenling: An emerging e-waste recycling city in Taizhou area, China. J. Hazard. Mater. 2010, 173, 653-660. [CrossRef]

5. Yang, K.; Zhu, L.; Xing, B. Enhanced Soil Washing of Phenanthrene by Mixed Solutions of TX100 and SDBS. Environ. Sci. Technol. 2006, 40, 4274-4280. [CrossRef] [PubMed]

6. Ren, L.; Lu, H.; He, L.; Zhang, Y. Enhanced electrokinetic technologies with oxidization-reduction for organically-contaminated soil remediation. Chem. Eng. J. 2014, 247, 111-124. [CrossRef] 
7. Meers, E.; Tack, F.M.G.; Verloo, M. Degradability of ethylenediaminedisuccinic acid (EDDS) in metal contaminated soils: Implications for its use soil remediation. Chemosphere 2008, 70, 358-363. [CrossRef] [PubMed]

8. Lehmann, J. A handful of carbon. Nature 2007, 447, 143-144. [CrossRef] [PubMed]

9. Ahmad, M.; Rajapaksha, A.U.; Lim, J.E.; Zhang, M.; Bolan, N.; Mohan, D.; Vithanage, M.; Lee, S.S.; Ok, Y.S. Biochar as a sorbent for contaminant management in soil and water: A review. Chemosphere 2014, 99, $19-33$. [CrossRef] [PubMed]

10. Godlewska, P.; Schmidt, H.P.; Ok, Y.S.; Oleszczuk, P. Biochar for composting improvement and contaminants reduction. A review. Bioresour. Technol. 2017, 246, 193-202. [CrossRef]

11. Cha, J.S.; Park, S.H.; Jung, S.-C.; Ryu, C.; Jeon, J.-K.; Shin, M.-C.; Park, Y.-K. Production and utilization of biochar: A review. J. Ind. Eng. Chem. 2016, 40, 1-15. [CrossRef]

12. Zwieten, L.V.; Kimber, S.; Morris, S.; Chan, K.Y.; Downie, A.; Rust, J.; Joseph, S.; Cowie, A. Effects of biochar from slow pyrolysis of papermill waste on agronomic performance and soil fertility. Plant Soil 2010, 327, 235-246. [CrossRef]

13. Liu, Z.; Quek, A.; Hoekman, S.K.; Balasubramanian, R. Production of solid biochar fuel from waste biomass by hydrothermal carbonization. Fuel 2013, 103, 943-949. [CrossRef]

14. Yu, F.; Deng, S.; Chen, P.; Liu, Y.; Wan, Y.; Olson, A.; Kittelson, D.; Ruan, R. Physical and Chemical Properties of Bio-Oils from Microwave Pyrolysis of Corn Stover. Appl. Biochem. Biotecnol. 2007, 137, 957-970.

15. Sabio, E.; Álvarez-Murillo, A.; Román, S.; Ledesma, B. Conversion of tomato-peel waste into solid fuel by hydrothermal carbonization: Influence of the processing variables. Waste Manag. 2016, 47, 122-132. [CrossRef] [PubMed]

16. Afolabi, O.O.; Sohail, M.; Thomas, C. Characterization of solid fuel chars recovered from microwave hydrothermal carbonization of human biowaste. Energy 2017, 134, 74-89. [CrossRef]

17. Liu, J.; Zhang, C.; Guo, S.; Xu, L.; Xiao, S.; Shen, Z. Microwave treatment of pre-oxidized fibers for improving their structure and mechanical properties. Ceram. Int. 2019, 45, 1379-1384. [CrossRef]

18. Laird, D.A.; Brown, R.C.; Amonette, J.E.; Lehmann, J. Review of the pyrolysis platform for coproducing bio-oil and biochar. Biofuels Bioprod. Biorefining 2009, 3, 547-562. [CrossRef]

19. Tan, Z.; Lin, C.S.; Ji, X.; Rainey, T.J. Returning biochar to fields: A review. Appl. Soil Ecol. 2017, 116, 1-11. [CrossRef]

20. Williams, P.T.; Besler, S. The pyrolysis of rice husks in a thermogravimetric analyser and static batch reactor. Fuel 1993, 72, 151-159. [CrossRef]

21. Crombie, K.; Mašek, O.; Sohi, S.P.; Brownsort, P.; Cross, A. The effect of pyrolysis conditions on biochar stability as determined by three methods. Gcb Bioenergy 2013, 5, 122-131. [CrossRef]

22. Enders, A.; Hanley, K.; Whitman, T.; Joseph, S.; Lehmann, J. Characterization of biochars to evaluate recalcitrance and agronomic performance. Bioresour. Technol. 2012, 114, 644-653. [CrossRef]

23. Yuan, J.-H.; Xu, R.-K.; Zhang, H. The forms of alkalis in the biochar produced from crop residues at different temperatures. Bioresour. Technol. 2011, 102, 3488-3497. [CrossRef] [PubMed]

24. Park, J.H.; Ok, Y.S.; Kim, S.H.; Cho, J.S.; Heo, J.S.; Delaune, R.D.; Seo, D.C. Evaluation of phosphorus adsorption capacity of sesame straw biochar on aqueous solution: Influence of activation methods and pyrolysis temperatures. Environ. Geochem. Health 2015, 37, 969-983. [CrossRef] [PubMed]

25. Meyer, S.; Glaser, B.; Quicker, P. Technical, Economical, and Climate-Related Aspects of Biochar Production Technologies: A Literature Review. Environ. Sci. Technol. 2011, 45, 9473-9483. [CrossRef] [PubMed]

26. Bruun, E.W.; Ambus, P.; Egsgaard, H.; Hauggaard-Nielsen, H. Effects of slow and fast pyrolysis biochar on soil C and N turnover dynamics. Soil Boil. Biochem. 2012, 46, 73-79. [CrossRef]

27. Mohan, D.; Pittman, C.U.; Steele, P.H. Pyrolysis of Wood/Biomass for Bio-oil: A Critical Review. Energy Fuel 2006, 20, 848-889. [CrossRef]

28. Bech, N.; Larsen, M.B.; Jensen, P.A.; Dam-Johansen, K. Modelling solid-convective flash pyrolysis of straw and wood in the Pyrolysis Centrifuge Reactor. Biomass Bioenergy 2009, 33, 999-1011. [CrossRef]

29. Chen, B.; Chen, Z.; Lv, S. A novel magnetic biochar efficiently sorbs organic pollutants and phosphate. Bioresour. Technol. 2011, 102, 716-723. [CrossRef] [PubMed]

30. Lu, G.Q.; Low, J.C.F.; Liu, C.Y.; Lua, A.C. Surface area development sludge during pyrolysis of sewage. Fuel 1995, 74, 344-348. [CrossRef] 
31. Tay, J.; Chen, X.; Jeyaseelan, S.; Graham, N. Optimising the preparation of activated carbon from digested sewage sludge and coconut husk. Chemosphere 2001, 44, 45-51. [CrossRef]

32. Jimenez-Cordero, D.; Heras, F.; Alonso-Morales, N.; Gilarranz, M.A.; Rodriguez, J.J. Ozone as oxidation agent in cyclic activation of biochar. Fuel Process. Technol. 2015, 139, 42-48. [CrossRef]

33. Chen, D.; Zheng, Z.; Fu, K.; Zeng, Z.; Wang, J.; Lu, M. Torrefaction of biomass stalk and its effect on the yield and quality of pyrolysis products. Fuel 2015, 159, 27-32. [CrossRef]

34. Mochidzuki, K.; Soutric, F.; Tadokoro, K.; Antal, M.J.; Toth, M.; Zelei, B.; Várhegyi, G. Electrical and Physical Properties of Carbonized Charcoals. Ind. Eng. Chem. Res. 2003, 42, 5140-5151. [CrossRef]

35. A Metz, L.; Meruva, N.K.; Morgan, S.L.; Goode, S.R. UV laser pyrolysis fast gas chromatography/ time-of-flight mass spectrometry for rapid characterization of synthetic polymers: Optimization of instrumental parameters. J. Anal. Appl. 2004, 71, 327-341. [CrossRef]

36. Tang, L.; Huang, H. Plasma Pyrolysis of Biomass for Production of Syngas and Carbon Adsorbent. Energy Fuels 2005, 19, 1174-1178. [CrossRef]

37. Yaman, S. Pyrolysis of Biomass to Produce Fuels and Chemical Feedstocks. ChemInform 2004, 35, 651-671. [CrossRef]

38. Lian, F.; Sun, B.; Song, Z.; Zhu, L.; Qi, X.; Xing, B. Physicochemical properties of herb-residue biochar and its sorption to ionizable antibiotic sulfamethoxazole. Chem. Eng. J. 2014, 248, 128-134. [CrossRef]

39. Song, Z.; Lian, F.; Yu, Z.; Zhu, L.; Xing, B.; Qiu, W. Synthesis and characterization of a novel MnOx-loaded biochar and its adsorption properties for $\mathrm{Cu}^{2+}$ in aqueous solution. Chem. Eng. J. 2014, 242, 36-42. [CrossRef]

40. Van Vinh, N.; Zafar, M.; Behera, S.K.; Park, H.S. Arsenic(III) removal from aqueous solution by raw and zinc-loaded pine cone biochar: Equilibrium, kinetics, and thermodynamics studies. Int. J. Environ. Sci. Technol. 2015, 12, 1283-1294. [CrossRef]

41. Liu, P.; Liu, W.-J.; Jiang, H.; Chen, J.-J.; Li, W.-W.; Yu, H.-Q. Modification of bio-char derived from fast pyrolysis of biomass and its application in removal of tetracycline from aqueous solution. Bioresour. Technol. 2012, 121, 235-240. [CrossRef] [PubMed]

42. Sun, Y.; Gao, B.; Yao, Y.; Fang, J.; Zhang, M.; Zhou, Y.; Chen, H.; Yang, L. Effects of feedstock type, production method, and pyrolysis temperature on biochar and hydrochar properties. Chem. Eng. J. 2014, 240, 574-578. [CrossRef]

43. Yin, Q.; Ren, H.; Wang, R.; Zhao, Z. Evaluation of nitrate and phosphate adsorption on Al-modified biochar: Influence of Al content. Sci. Total Environ. 2018, 631, 895-903. [CrossRef] [PubMed]

44. Rajapaksha, A.U.; Vithanage, M.; Ahmad, M.; Seo, D.-C.; Cho, J.-S.; Lee, S.-E.; Lee, S.S.; Ok, Y.S. Enhanced sulfamethazine removal by steam-activated invasive plant-derived biochar. J. Hazard. Mater. 2015, 290, 43-50. [CrossRef] [PubMed]

45. Wang, S.; Gao, B.; Li, Y.; Mosa, A.; Zimmerman, A.R.; Ma, L.Q.; Harris, W.G.; Migliaccio, K.W. Manganese oxide-modified biochars: Preparation, characterization, and sorption of arsenate and lead. Bioresour. Technol. 2015, 181, 13-17. [CrossRef] [PubMed]

46. Jung, K.-W.; Hwang, M.-J.; Jeong, T.-U.; Ahn, K.-H. A novel approach for preparation of modified-biochar derived from marine macroalgae: Dual purpose electro-modification for improvement of surface area and metal impregnation. Bioresour. Technol. 2015, 191, 342-345. [CrossRef] [PubMed]

47. Jin, H.; Capareda, S.; Chang, Z.; Gao, J.; Xu, Y.; Zhang, J. Biochar pyrolytically produced from municipal solid wastes for aqueous $\mathrm{As}(\mathrm{V})$ removal: Adsorption property and its improvement with $\mathrm{KOH}$ activation. Bioresour. Technol. 2014, 169, 622-629. [CrossRef]

48. Chen, T.; Luo, L.; Deng, S.; Shi, G.; Zhang, S.; Zhang, Y.; Deng, O.; Wang, L.; Zhang, J.; Wei, L. Sorption of tetracycline on $\mathrm{H}_{3} \mathrm{PO}_{4}$ modified biochar derived from rice straw and swine manure. Bioresour. Technol. 2018, 267, 431-437. [CrossRef]

49. Li, Y.; Wei, Y.; Huang, S.; Liu, X.; Jin, Z.; Zhang, M.; Qu, J.; Jin, Y. Biosorption of Cr(VI) onto Auricularia auricula dreg biochar modified by cationic surfactant: Characteristics and mechanism. J. Mol. Liq. 2018, 269, 824-832. [CrossRef]

50. Tao, Q.; Li, B.; Li, Q.; Han, X.; Jiang, Y.; Jupa, R.; Wang, C.; Li, T. Simultaneous remediation of sediments contaminated with sulfamethoxazole and cadmium using magnesium-modified biochar derived from Thalia dealbata. Sci. Total Environ. 2019, 659, 1448-1456. [CrossRef] 
51. Tan, G.; Sun, W.; Xu, Y.; Wang, H.; Xu, N. Sorption of mercury (II) and atrazine by biochar, modified biochars and biochar based activated carbon in aqueous solution. Bioresour. Technol. 2016, 211, 727-735. [CrossRef] [PubMed]

52. Kim, K.H.; Kim, J.-Y.; Cho, T.-S.; Choi, J.W. Influence of pyrolysis temperature on physicochemical properties of biochar obtained from the fast pyrolysis of pitch pine (Pinus rigida). Bioresour. Technol. 2012, 118, 158-162. [CrossRef]

53. Sun, B.; Lian, F.; Bao, Q.; Liu, Z.; Song, Z.; Zhu, L. Impact of low molecular weight organic acids (LMWOAs) on biochar micropores and sorption properties for sulfamethoxazole. Environ. Pollut. 2016, 214, 142-148. [CrossRef] [PubMed]

54. Yao, Y.; Gao, B.; Inyang, M.; Zimmerman, A.R.; Cao, X.; Pullammanappallil, P.; Yang, L. Biochar derived from anaerobically digested sugar beet tailings: Characterization and phosphate removal potential. Bioresour. Technol. 2011, 102, 6273-6278. [CrossRef]

55. Rajapaksha, A.U.; Vithanage, M.; Zhang, M.; Ahmad, M.; Mohan, D.; Chang, S.X.; Ok, Y.S. Pyrolysis condition affected sulfamethazine sorption by tea waste biochars. Bioresour. Technol. 2014, 166, 303-308. [CrossRef] [PubMed]

56. Dong, H.; Deng, J.; Xie, Y.; Zhang, C.; Jiang, Z.; Cheng, Y.; Hou, K.; Zeng, G. Stabilization of nanoscale zero-valent iron (nZVI) with modified biochar for $\mathrm{Cr}(\mathrm{VI})$ removal from aqueous solution. J. Hazard. Mater. 2017, 332, 79-86. [CrossRef]

57. Kołodyńska, D.; Krukowska, J.; Thomas, P. Comparison of sorption and desorption studies of heavy metal ions from biochar and commercial active carbon. Chem. Eng. J. 2017, 307, 353-363. [CrossRef]

58. Fu, D.; Chen, Z.; Xia, D.; Shen, L.; Wang, Y.; Li, Q. A novel solid digestate-derived biochar-Cu NP composite activating $\mathrm{H}_{2} \mathrm{O}_{2}$ system for simultaneous adsorption and degradation of tetracycline. Environ. Pollut. 2017, 221, 301-310. [CrossRef]

59. Zuo, X.J.; Liu, Z.; Chen, M.D. Effect of $\mathrm{H}_{2} \mathrm{O}_{2}$ concentrations on copper removal using the modified hydrothermal biochar. Bioresour. Technol. 2016, 207, 262-267. [CrossRef]

60. Zhao, L.; Zheng, W.; Mašek, O.; Chen, X.; Gu, B.; Sharma, B.K.; Cao, X. Roles of Phosphoric Acid in Biochar Formation: Synchronously Improving Carbon Retention and Sorption Capacity. J. Environ. Qual. 2017, 46, 393. [CrossRef]

61. Ho, P.H.; Lee, S.-Y.; Lee, D.; Woo, H.-C. Selective adsorption of tert-butylmercaptan and tetrahydrothiophene on modified activated carbons for fuel processing in fuel cell applications. Int. J. Hydrogen Energy 2014, 39, 6737-6745. [CrossRef]

62. Zhang, Q.-P.; Liu, Q.-C.; Li, B.; Yang, L.; Wang, C.-Q.; Li, Y.-D.; Xiao, R. Adsorption of Cd(II) from aqueous solutions by rape straw biochar derived from different modification processes. Chemosphere 2017, 175, 332-340.

63. Wang, M.; Wang, J.J.; Wang, X. Effect of KOH-enhanced biochar on increasing soil plant-available silicon. Geoderma 2018, 321, 22-31. [CrossRef]

64. Li, L.; Liu, S.; Liu, J. Surface modification of coconut shell based activated carbon for the improvement of hydrophobic VOC removal. J. Hazard. Mater. 2011, 192, 683-690. [CrossRef]

65. Sizmur, T.; Fresno, T.; Akgül, G.; Frost, H.; Jiménez, E.M. Biochar modification to enhance sorption of inorganics from water. Bioresour. Technol. 2017, 246, 34-47. [CrossRef]

66. Pouretedal, H.; Sadegh, N. Effective removal of Amoxicillin, Cephalexin, Tetracycline and Penicillin G from aqueous solutions using activated carbon nanoparticles prepared from vine wood. J. Process. Eng. 2014, 1, 64-73. [CrossRef]

67. Yin, Z.; Liu, Y.; Liu, S.; Jiang, L.; Tan, X.; Zeng, G.; Li, M.; Liu, S.; Tian, S.; Fang, Y. Activated magnetic biochar by one-step synthesis: Enhanced adsorption and coadsorption for $17 \beta$-estradiol and copper. Sci. Total Environ. 2018, 639, 1530-1542. [CrossRef]

68. Li, R.; Wang, J.J.; Zhou, B.; Awasthi, M.K.; Ali, A.; Zhang, Z.; Gaston, L.A.; Lahori, A.H.; Mahar, A. Enhancing phosphate adsorption by $\mathrm{Mg} / \mathrm{Al}$ layered double hydroxide functionalized biochar with different $\mathrm{Mg} / \mathrm{Al}$ ratios. Sci. Total Environ. 2016, 559, 121-129. [CrossRef]

69. Wu, H.; Feng, Q.; Yang, H.; Alam, E.; Gao, B.; Gu, D. Modified biochar supported Ag/Fe nanoparticles used for removal of cephalexin in solution: Characterization, kinetics and mechanisms. Colloids Surf. A Physicochem. Eng. Asp. 2017, 517, 63-71. [CrossRef] 
70. Angın, D.; Altintig, E.; Köse, T.E. Influence of process parameters on the surface and chemical properties of activated carbon obtained from biochar by chemical activation. Bioresour. Technol. 2013, 148, 542-549. [CrossRef]

71. Lyu, H.; Tang, J.; Huang, Y.; Gai, L.; Zeng, E.Y.; Liber, K.; Gong, Y. Removal of hexavalent chromium from aqueous solutions by a novel biochar supported nanoscale iron sulfide composite. Chem. Eng. J. 2017, 322, 516-524. [CrossRef]

72. Bird, M.I.; Charville-Mort, P.D.; Ascough, P.L.; Wood, R.; Higham, T.; Apperley, D. Assessment of oxygen plasma ashing as a pre-treatment for radiocarbon dating. Quat. Geochronol. 2010, 5, 435-442. [CrossRef]

73. Wu, G.-Q.; Zhang, X.; Hui, H.; Yan, J.; Zhang, Q.-S.; Wan, J.-L.; Dai, Y. Adsorptive removal of aniline from aqueous solution by oxygen plasma irradiated bamboo based activated carbon. Chem. Eng. J. 2012, 185, 201-210. [CrossRef]

74. Wang, S.; Zhou, Y.; Han, S.; Wang, N.; Yin, W.; Yin, X.; Gao, B.; Wang, X.; Wang, J. Carboxymethyl cellulose stabilized $\mathrm{ZnO} /$ biochar nanocomposites: Enhanced adsorption and inhibited photocatalytic degradation of methylene blue. Chemosphere 2018, 197, 20-25. [CrossRef]

75. Tendero, C.; Tixier, C.; Tristant, P.; Desmaison, J.; Leprince, P. Atmospheric pressure plasmas: A review. Spectrochim. B At. Spectrosc. 2006, 61, 2-30. [CrossRef]

76. Wu, C.; Shi, L.; Xue, S.; Li, W.; Jiang, X.; Rajendran, M.; Qian, Z. Effect of sulfur-iron modified biochar on the available cadmium and bacterial community structure in contaminated soils. Sci. Total Environ. 2019, 647, 1158-1168. [CrossRef]

77. Jin, J.; Li, S.; Peng, X.; Liu, W.; Zhang, C.; Yang, Y.; Han, L.; Du, Z.; Sun, K.; Wang, X. $\mathrm{HNO}_{3}$ modified biochars for uranium (VI) removal from aqueous solution. Bioresour. Technol. 2018, 256, 247-253. [CrossRef]

78. Liu, H.; Xu, F.; Xie, Y.; Wang, C.; Zhang, A.; Li, L.; Xu, H. Effect of modified coconut shell biochar on availability of heavy metals and biochemical characteristics of soil in multiple heavy metals contaminated soil. Sci. Total Environ. 2018, 645, 702-709. [CrossRef]

79. Chen, Z.-L.; Zhang, J.-Q.; Huang, L.; Yuan, Z.-H.; Li, Z.-J.; Liu, M.-C. Removal of Cd and Pb with biochar made from dairy manure at low temperature. J. Integr. Agric. 2019, 18, 201-210. [CrossRef]

80. Hassan, M.M.; Carr, C.M. A critical review on recent advancements of the removal of reactive dyes from dyehouse effluent by ion-exchange adsorbents. Chemosphere 2018, 209, 201-219. [CrossRef]

81. Ko, D.C.; Cheung, C.W.; Choy, K.K.; Porter, J.F.; McKay, G. Sorption equilibria of metal ions on bone char. Chemosphere 2004, 54, 273-281. [CrossRef]

82. Ngah, W.W.; Hanafiah, M.; Hanafiah, M.A.K.M. Removal of heavy metal ions from wastewater by chemically modified plant wastes as adsorbents: A review. Bioresour. Technol. 2008, 99, 3935-3948. [CrossRef]

83. Sarı, A.; Tuzen, M. Kinetic and equilibrium studies of biosorption of $\mathrm{Pb}$ (II) and $\mathrm{Cd}$ (II) from aqueous solution by macrofungus (Amanita rubescens) biomass. J. Hazard. Mater. 2009, 164, 1004-1011. [CrossRef]

84. Ho, Y.; McKay, G. Pseudo-second order model for sorption processes. Process. Biochem. 1999, 34, 451-465. [CrossRef]

85. Qiu, Y.; Xiao, X.; Cheng, H.; Zhou, Z.; Sheng, G.D. Influence of Environmental Factors on Pesticide Adsorption by Black Carbon: $\mathrm{pH}$ and Model Dissolved Organic Matter. Environ. Sci. Technol. 2009, 43, 4973-4978. [CrossRef]

86. Chun, Y.; Sheng, G.; Chiou, C.T.; Xing, B. Compositions and Sorptive Properties of Crop Residue-Derived Chars. Environ. Sci. Technol. 2004, 38, 4649-4655. [CrossRef]

87. Pan, J.; Jiang, J.; Xu, R. Adsorption of $\mathrm{Cr}$ (III) from acidic solutions by crop straw derived biochars. J. Environ. Sci. 2013, 25, 1957-1965. [CrossRef]

88. Uchimiya, M.; Lima, I.M.; Klasson, K.T.; Chang, S.; Wartelle, L.H.; Rodgers, J.E. Immobilization of Heavy Metal Ions (CuII, CdII, NiII, and PbII) by Broiler Litter-Derived Biochars in Water and Soil. J. Agric. Chem. 2010, 58, 5538-5544. [CrossRef]

89. Sohi, S.; Krull, E.; Lopez-Capel, E.; Bol, R. A Review of Biochar and Its Use and Function in Soil. Adv. Agron. 2010, 105, 47-82.

90. Tang, J.; Zhu, W.; Kookana, R.; Katayama, A. Characteristics of biochar and its application in remediation of contaminated soil. J. Biosci. Bioeng. 2013, 116, 653-659. [CrossRef]

91. Xu, R.-K.; Xiao, S.-C.; Yuan, J.-H.; Zhao, A.-Z. Adsorption of methyl violet from aqueous solutions by the biochars derived from crop residues. Bioresour. Technol. 2011, 102, 10293-10298. [CrossRef] [PubMed] 
92. Xu, X.; Cao, X.; Zhao, L.; Wang, H.; Yu, H.; Gao, B. Removal of Cu, Zn, and Cd from aqueous solutions by the dairy manure-derived biochar. Environ. Sci. Pollut. Res. 2013, 20, 358-368. [CrossRef]

93. Qian, L.; Chen, B.; Hu, D. Effective Alleviation of Aluminum Phytotoxicity by Manure-Derived Biochar. Environ. Sci. Technol. 2013, 47, 2737-2745. [CrossRef]

94. Jia, M.; Wang, F.; Bian, Y.; Jin, X.; Song, Y.; Kengara, F.O.; Xu, R.; Jiang, X. Effects of pH and metal ions on oxytetracycline sorption to maize-straw-derived biochar. Bioresour. Technol. 2013, 136, 87-93. [CrossRef] [PubMed]

95. Chen, T.; Zhou, Z.; Han, R.; Meng, R.; Wang, H.; Lu, W. Adsorption of cadmium by biochar derived from municipal sewage sludge: Impact factors and adsorption mechanism. Chemosphere 2015, 134, $286-293$. [CrossRef]

96. Yu, H.; Liu, J.; Shen, J.; Sun, X.; Li, J.; Wang, L. Preparation of MnOx-loaded biochar for $\mathrm{Pb}^{2+}$ removal: Adsorption performance and possible mechanism. J. Taiwan Inst. Chem. Eng. 2016, 66, 313-320.

97. Qian, T.; Wang, Y.; Fan, T.; Fang, G.; Zhou, D. A new insight into the immobilization mechanism of Zn on biochar: The role of anions dissolved from ash. Sci. Rep. 2016, 6, 33630. [CrossRef] [PubMed]

98. Ahmed, M.B.; Zhou, J.L.; Ngo, H.H.; Guo, W.; Johir, M.A.H.; Sornalingam, K.; Rahman, M.S. Chloramphenicol interaction with functionalized biochar in water: Sorptive mechanism, molecular imprinting effect and repeatable application. Sci. Total Environ. 2017, 609, 885-895. [CrossRef]

99. Dong, X.; Ma, L.Q.; Li, Y. Characteristics and mechanisms of hexavalent chromium removal by biochar from sugar beet tailing. J. Hazard. Mater. 2011, 190, 909-915. [CrossRef]

100. Li, H.; Dong, X.; Da Silva, E.B.; De Oliveira, L.M.; Chen, Y.; Ma, L.Q. Mechanisms of metal sorption by biochars: Biochar characteristics and modifications. Chemosphere 2017, 178, 466-478. [CrossRef] [PubMed]

101. Samsuri, A.W.; Sadegh-Zadeh, F.; Seh-Bardan, B.J. Adsorption of As(III) and As(V) by Fe coated biochars and biochars produced from empty fruit bunch and rice husk. J. Environ. Chem. Eng. 2013, 1, 981-988. [CrossRef]

102. Ahmed, M.B.; Zhou, J.L.; Ngo, H.H.; Guo, W.; Johir, M.A.H.; Sornalingam, K. Single and competitive sorption properties and mechanism of functionalized biochar for removing sulfonamide antibiotics from water. Chem. Eng. J. 2017, 311, 348-358. [CrossRef]

103. Boostani, H.R.; Najafi-Ghiri, M.; Hardie, A.G.; Khalili, D. Comparison of Pb stabilization in a contaminated calcareous soil by application of vermicompost and sheep manure and their biochars produced at two temperatures. Appl. Geochem. 2019, 102, 121-128. [CrossRef]

104. Kim, H.-S.; Kim, K.-R.; Kim, H.-J.; Yoon, J.-H.; Yang, J.E.; Ok, Y.S.; Owens, G.; Kim, K.-H. Effect of biochar on heavy metal immobilization and uptake by lettuce (Lactuca sativa L.) in agricultural soil. Environ. Earth Sci. 2015, 74, 1249-1259. [CrossRef]

105. Yang, X.; Liu, J.; McGrouther, K.; Huang, H.; Lu, K.; Guo, X.; He, L.; Lin, X.; Che, L.; Ye, Z.; Wang, H. Effect of biochar on the extractability of heavy metals $(\mathrm{Cd}, \mathrm{Cu}, \mathrm{Pb}$, and $\mathrm{Zn})$ and enzyme activity in soil. Environ. Sci. Pollut. Res. 2016, 23, 974. [CrossRef]

106. Zhou, D.; Liu, D.; Gao, F.; Li, M.; Luo, X. Effects of Biochar-Derived Sewage Sludge on Heavy Metal Adsorption and Immobilization in Soils. Int. J. Environ. Res. Public Health 2017, 14, 681. [CrossRef]

107. Wang, Y.; Zhong, B.; Shafi, M.; Ma, J.; Guo, J.; Wu, J.; Ye, Z.; Liu, D.; Jin, H. Effects of biochar on growth, and heavy metals accumulation of moso bamboo (Phyllostachy pubescens), soil physical properties, and heavy metals solubility in soil. Chemosphere 2019, 219, 510-516. [CrossRef]

108. Penido, E.S.; Martins, G.C.; Mendes, T.B.M.; Melo, L.C.A.; Guimarães, I.D.R.; Guilherme, L.R.G. Combining biochar and sewage sludge for immobilization of heavy metals in mining soils. Ecotoxicol. Environ. Saf. 2019, 172, 326-333. [CrossRef]

109. Lu, H.; Li, Z.; Gascó, G.; Méndez, A.; Shen, Y.; Paz-Ferreiro, J. Use of magnetic biochars for the immobilization of heavy metals in a multi-contaminated soil. Sci. Total. Environ. 2018, 622, 892-899. [CrossRef] [PubMed]

110. Jia, W.; Wang, B.; Wang, C.; Sun, H. Tourmaline and biochar for the remediation of acid soil polluted with heavy metals. J. Environ. Chem. Eng. 2017, 5, 2107-2114. [CrossRef]

111. Khan, M.A.; Khan, S.; Ding, X.; Khan, A.; Alam, M. The effects of biochar and rice husk on adsorption and desorption of cadmium on to soils with different water conditions (upland and saturated). Chemosphere 2018, 193, 1120-1126. [CrossRef] [PubMed]

112. Kumarathilaka, P.; Ahmad, M.; Herath, I.; Mahatantila, K.; Athapattu, B.; Rinklebe, J.; Ok, Y.S.; Usman, A.; Al-Wabel, M.I.; Abduljabbar, A.; et al. Influence of bioenergy waste biochar on proton- and ligand-promoted release of $\mathrm{Pb}$ and $\mathrm{Cu}$ in a shooting range soil. Sci. Total. Environ. 2018, 625, 547-554. [CrossRef] 
113. Mandal, S.; Sarkar, B.; Bolan, N.; Ok, Y.S.; Naidu, R. Enhancement of chromate reduction in soils by surface modified biochar. J. Environ. Manag. 2017, 186, 277-284. [CrossRef]

114. Monser, L.; Ben Amor, M.; Ksibi, M. Purification of wet phosphoric acid using modified activated carbon. Chem. Eng. Process. Process. Intensif. 1999, 38, 267-271. [CrossRef]

115. Lin, L.; Li, Z.; Liu, X.; Qiu, W.; Song, Z. Effects of Fe-Mn modified biochar composite treatment on the properties of As-polluted paddy soil. Environ. Pollut. 2019, 244, 600-607. [CrossRef]

116. O'Connor, D.; Peng, T.; Li, G.; Wang, S.; Duan, L.; Mulder, J.; Cornelissen, G.; Cheng, Z.; Yang, S.; Hou, D. Sulfur-modified rice husk biochar: A green method for the remediation of mercury contaminated soil. Sci. Total. Environ. 2018, 621, 819-826. [CrossRef]

117. Yu, Z.; Zhou, L.; Huang, Y.; Song, Z.; Qiu, W. Effects of a manganese oxide-modified biochar composite on adsorption of arsenic in red soil. J. Environ. Manag. 2015, 163, 155-162. [CrossRef] [PubMed]

118. Gu, J.; Zhou, W.; Jiang, B.; Wang, L.; Ma, Y.; Guo, H.; Schulin, R.; Ji, R.; Evangelou, M.W. Effects of biochar on the transformation and earthworm bioaccumulation of organic pollutants in soil. Chemosphere 2016, 145, 431-437. [CrossRef]

119. Bielská, L.; Škulcová, L.; Neuwirthová, N.; Cornelissen, G.; Hale, S.E. Sorption, bioavailability and ecotoxic effects of hydrophobic organic compounds in biochar amended soils. Sci. Total Environ. 2018, 624, 78-86. [CrossRef] [PubMed]

120. Wu, C.; Liu, X.; Wu, X.; Dong, F.; Xu, J.; Zheng, Y. Sorption, degradation and bioavailability of oxyfluorfen in biochar-amended soils. Sci. Total Environ. 2019, 658, 87-94. [CrossRef] [PubMed]

121. Rombolà, A.G.; Fabbri, D.; Baronti, S.; Vaccari, F.P.; Genesio, L.; Miglietta, F. Changes in the pattern of polycyclic aromatic hydrocarbons in soil treated with biochar from a multiyear field experiment. Chemosphere 2019, 219, 662-670. [CrossRef] [PubMed]

122. Kołtowski, M.; Hilber, I.; Bucheli, T.D.; Charmas, B.; Skubiszewska-Zięba, J.; Oleszczuk, P. Activated biochars reduce the exposure of polycyclic aromatic hydrocarbons in industrially contaminated soils. Chem. Eng. J. 2017, 310, 33-40. [CrossRef]

123. Zhang, P.; Sun, H.; Min, L.; Ren, C. Biochars change the sorption and degradation of thiacloprid in soil: Insights into chemical and biological mechanisms. Environ. Pollut. 2018, 236, 158-167. [CrossRef] [PubMed]

124. Yu, H.; Zou, W.; Chen, J.; Chen, H.; Yu, Z.; Huang, J.; Tang, H.; Wei, X.; Gao, B. Biochar amendment improves crop production in problem soils: A review. J. Environ. Manag. 2019, 232, 8-21. [CrossRef] [PubMed]

125. Bayabil, H.K.; Stoof, C.R.; Lehmann, J.C.; Yitaferu, B.; Steenhuis, T.S. Assessing the potential of biochar and charcoal to improve soil hydraulic properties in the humid Ethiopian Highlands: The Anjeni watershed. Geoderma 2015, 243, 115-123. [CrossRef]

126. Liu, X.; Li, L.; Bian, R.; Chen, D.; Qu, J.; Wanjiru Kibue, G.; Pan, G.; Zhang, X.; Zheng, J.; Zheng, J. Effect of biochar amendment on soil-silicon availability and rice uptake. J. Plant Nutr. Soil Sci. 2014, 177, 91-96. [CrossRef]

127. Agegnehu, G.; Bass, A.M.; Nelson, P.N.; Muirhead, B.; Wright, G.; Bird, M.I. Biochar and biochar-compost as soil amendments: Effects on peanut yield, soil properties and greenhouse gas emissions in tropical North Queensland, Australia. Agric. Ecosyst. Environ. 2015, 213, 72-85. [CrossRef]

128. Gul, S.; Whalen, J.K. Biochemical cycling of nitrogen and phosphorus in biochar-amended soils. Soil Boil. Biochem. 2016, 103, 1-15. [CrossRef]

129. Safaei Khorram, M.; Fatemi, A.; Khan, M.A.; Kiefer, R.; Jafarnia, S. Potential risk of weed outbreak by increasing biochar's application rates in slow-growth legume, lentil (Lens culinaris Medik.). J. Sci. Food Agric. 2018, 98, 2080-2088. [CrossRef]

130. Lian, F.; Xing, B. Black Carbon (Biochar) In Water/Soil Environments: Molecular Structure, Sorption, Stability, and Potential Risk. Environ. Sci. Technol. 2017, 51, 13517-13532. [CrossRef]

(C) 2019 by the authors. Licensee MDPI, Basel, Switzerland. This article is an open access article distributed under the terms and conditions of the Creative Commons Attribution (CC BY) license (http:/ / creativecommons.org/licenses/by/4.0/). 